\title{
The Link between Gaucher Disease and Parkinson's Disease Sheds Light on Old and Novel Disorders of Sphingolipid Metabolism
}

\author{
Rossella Indellicato ${ }^{1}$ and Marco Trinchera ${ }^{2, *}$ D \\ 1 Department of Health Science, University of Milan, 20142 Milano, Italy \\ 2 Department of Medicine and Surgery, University of Insubria, 21100 Varese, Italy \\ * Correspondence: marco.trinchera@uninsubria.it; Tel.: +39-0332-39-7160
}

Received: 6 June 2019; Accepted: 29 June 2019; Published: 5 July 2019

\begin{abstract}
Sphingolipid metabolism starts with the biosynthesis of ceramide, a bioactive lipid and the backbone for the biosynthesis of complex sphingolipids such as sphingomyelin and glycosphingolipids. These are degraded back to ceramide and then to sphingosine, which enters the ceramide-sphingosine-1-phosphate signaling pathway or is further degraded. Several enzymes with multiple catalytic properties and subcellular localizations are thus involved in such metabolism. Hereditary defects of lysosomal hydrolases have been known for several years to be the cause of lysosomal storage diseases such as gangliosidoses, Gaucher disease, Niemann-Pick disease, Krabbe disease, Fabry disease, and Farber disease. More recently, many other inborn errors of sphingolipid metabolism have been recognized, involving enzymes responsible for the biosynthesis of ceramide, sphingomyelin, and glycosphingolipids. Concurrently, epidemiologic and biochemical evidence has established a link between Gaucher disease and Parkinson's disease, showing that glucocerebrosidase variants predispose individuals to $\alpha$-synuclein accumulation and neurodegeneration even in the heterozygous status. This appears to be due not only to lysosomal overload of non-degraded glucosylceramide, but to the derangement of vesicle traffic and autophagy, including mitochondrial autophagy, triggered by both sphingolipid intermediates and misfolded proteins. In this review, old and novel disorders of sphingolipid metabolism, in particular those of ganglioside biosynthesis, are evaluated in light of recent investigations of the link between Gaucher disease and Parkinson's disease, with the aim of better understanding their pathogenic mechanisms and addressing new potential therapeutic strategies.
\end{abstract}

Keywords: autophagy; ganglioside; lysosome; rare disease

\section{Introduction}

Sphingolipid metabolism starts in the endoplasmic reticulum (ER) with the condensation of serine and palmitic acid, producing 3-keto-dihydrosphingosine (also named 3-keto-sphinganine), and it continues through successive enzymatic reactions leading to the synthesis of ceramide [1] (Figure 1). Ceramide plays several roles in cell homeostasis, itself acting as a regulator or through the generation of other bioactive lipids such as ceramide-1-phosphate and sphingosine-1-phosphate (S1P) [2]. Nevertheless, a large amount is used as the backbone for the biosynthesis of sphingomyelin (SM) and glycosphingolipids (GSLs) (Figure 2). In particular, ceramide is acted upon by UGT8, galactosylceramide (GalCer) synthase (see Tables 1-3 for enzyme symbols) in the ER [1], and SGMS, SM synthase [3] or UGCG, glucosylceramide (GlcCer) synthase [4] in the Golgi apparatus. GlcCer may undergo many different further glycosylations, giving rise to a plethora of GSLs, depending on the specific glycosyltransferase machinery present in the various cell types. These include gangliosides, 
globosides, and other neutral compounds (Figure 2). Ceramide, SM, and GSLs flow through the Golgi to the plasma membrane or other organelles (such as mitochondria in the case of ceramide) via vesicular-mediated [5] or protein-mediated traffic [6]. The plasma membrane is considered the main destination of such compounds, which may also be delivered outside the cell in the form of microvesicles [7] or channeled along the endocytic pathways toward phagosomes and lysosomes. In the lysosomes, complex sphingolipids are stepwise degraded to fatty acids and sphingosine (Figures 1 and 2). Sphingosine reaches the ER, where it enters the Cer-S1P signaling pathway. S1P can be also degraded to phosphoethanolamine and 2-hexadecenal [1] (Figure 1). Defects of specific lysosomal hydrolases (Table 1) involved in this process have been known for several years and constitute the main group of lysosomal storage disorders due to inborn errors of metabolism [8]. These include the gangliosidoses, Niemann-Pick disease, Fabry disease, Krabbe disease, Gaucher disease, and Farber disease. More recently, defects of several enzymes responsible for the biosynthetic steps (Tables 2 and 3) were found to be associated with human diseases: these include variants of serine palmitoyl transferases (SPTLC) [9,10], 3-keto-dihydro-sphingosine reductase (KDSR) [11-13], dihydro-ceramide synthases (CERS) [14-18], dihydroceramide desaturase (DEGS) [19-21], sphingomyelin synthases (SGMS) [22,23], GlcCer synthase (UGCG) [24], GM3 synthase (ST3GAL5), GM2/GD2/GA2 synthase (B4GALNT1), and CMP-Sial: GlcNAc $\beta 1,3(4)$ sialyltransferase (ST3GAL3) [25]. The latter four enzymes are glycosyltransferases and, thus, the related diseases belong to the wide family of the congenital disorders of glycosylation (CDG) [26]. It is worth noting that some enzymes of sphingolipid metabolism exist in different isoforms representing different gene products, sometimes with different subcellular localization, as in the case of ceramidases, ceramide synthases, sphingomyelinases, and SM synthases (Tables 1-3). It is not surprising that disorders involving different isoforms may produce very different clinical phenotypes. Variants of CERS1 and -2 result in a myoclonus epilepsy [14,15,17], while CERS3 variants determine a form of ichthyosis [16]. Glucocerebrosidase (GBA) variants are responsible for Gaucher disease (GD) [27], while GBA2 variants result in hereditary spastic paraplegia 46 (HSP46) [28]. Acid ceramidase ASAH1 deficiency is the cause of Farber disease [29], while alkaline ceramidase (ACER3) variants are responsible for progressive leucodystrophy [30]. Many of such disorders result in extremely heterogeneous clinical syndromes, in terms of both symptoms and severity, and some give rise to clinical features overlapping those of disorders involving totally unrelated genes [31]. GD is the most relevant example of the former. The clinical presentation ranges from a mild visceral impairment detectable in adulthood to a severe neurologic impairment that is lethal by early childhood, without a clear relationship with the underlying mutation or the amounts of residual enzyme activity $[27,32,33]$. On the other hand, B4GALNT1-CDG is one of about 70 known genetic defects determining an inherited spastic paraplegia [34], and ST3GAL3-CDG is reported as one of the many conditions causing West syndrome, potentially evolving to Lennox-Gestaut syndrome [35]. Many such disorders are typically transmitted in an autosomal recessive manner (see Tables 1-3). However, emerging data show that heterozygous carriers of glucocerebrosidase GBA [33], sphingomyelinase SMPD1 [36], galactocerebrosidase (GALC) [37], and $\alpha$-galactosidase (GLA) [38] variants are as much at risk for neurodegenerative diseases such as synucleopathies and multiple sclerosis as those with recessive homozygotes.

The purpose of this review is to evaluate recent data concerning disorders of sphingolipid metabolism where the pathogenic role played by the loss of function of enzymes appears unable to explain the whole picture, while other mechanisms seem to cooperate with the clinical phenotype. Among them, the emerging candidates include the impairment of vesicle traffic in the context of autophagy/lysosome function and altered trafficking and metabolism of the variant proteins. In this regard, the data on GD as the main risk factor for Parkinson's disease (PD) suggest that the GD/PD connection may represent a pathogenic paradigm able to shed light on other disorders of sphingolipid metabolism. In particular, we focus on those affecting ganglioside biosynthesis as the disorders where such aspects could be relevant. This is interesting not only to better understand sphingolipid biology and the disease pathogenesis, but to address novel potential therapeutic strategies. 


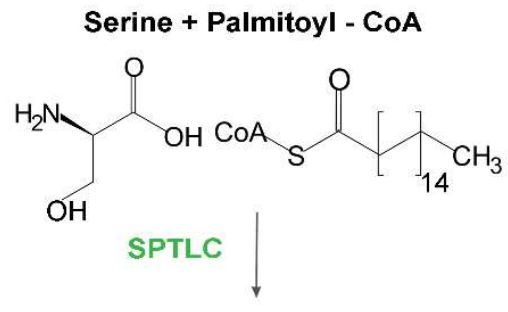

3 - keto - dihydrosphingosine<smiles>[R]O[R9]</smiles>

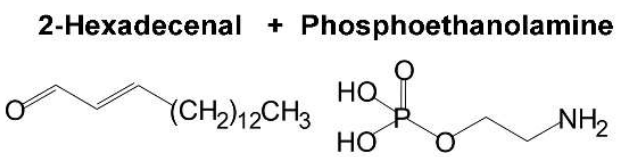

Dihydrosphingosine<smiles>CCCCCCC(O)C(N)CO</smiles><smiles>CCCCC=CC(O)C(N)COP(=O)(O)O</smiles>

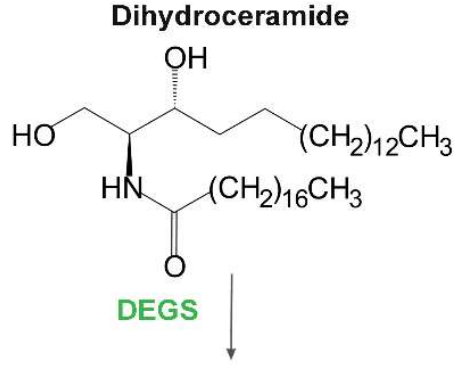<smiles>CCCCC=CC(O)C(N)CO</smiles>

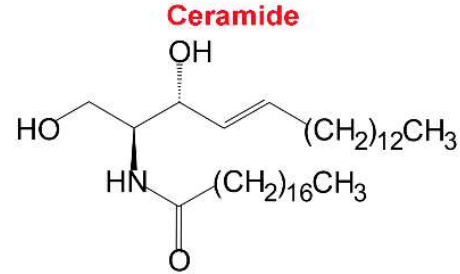

Figure 1. Biosynthesis and degradation of ceramide. SPTLC, serine palmitoyl transferase; KDSR, 3-keto-dihydro-sphingosine reductase; CERS, dihydroceramide synthase; DEGS, dihydroceramide desaturase; ASAH, acid ceramidase; ACER, alkaline ceramidase; SPHK, sphingosine kinase; SGPL1, sphingosine lyase. For simplicity, only stearic acid is depicted as the acyl chain of ceramides, but longer fatty acids can be added by different CERSs. 


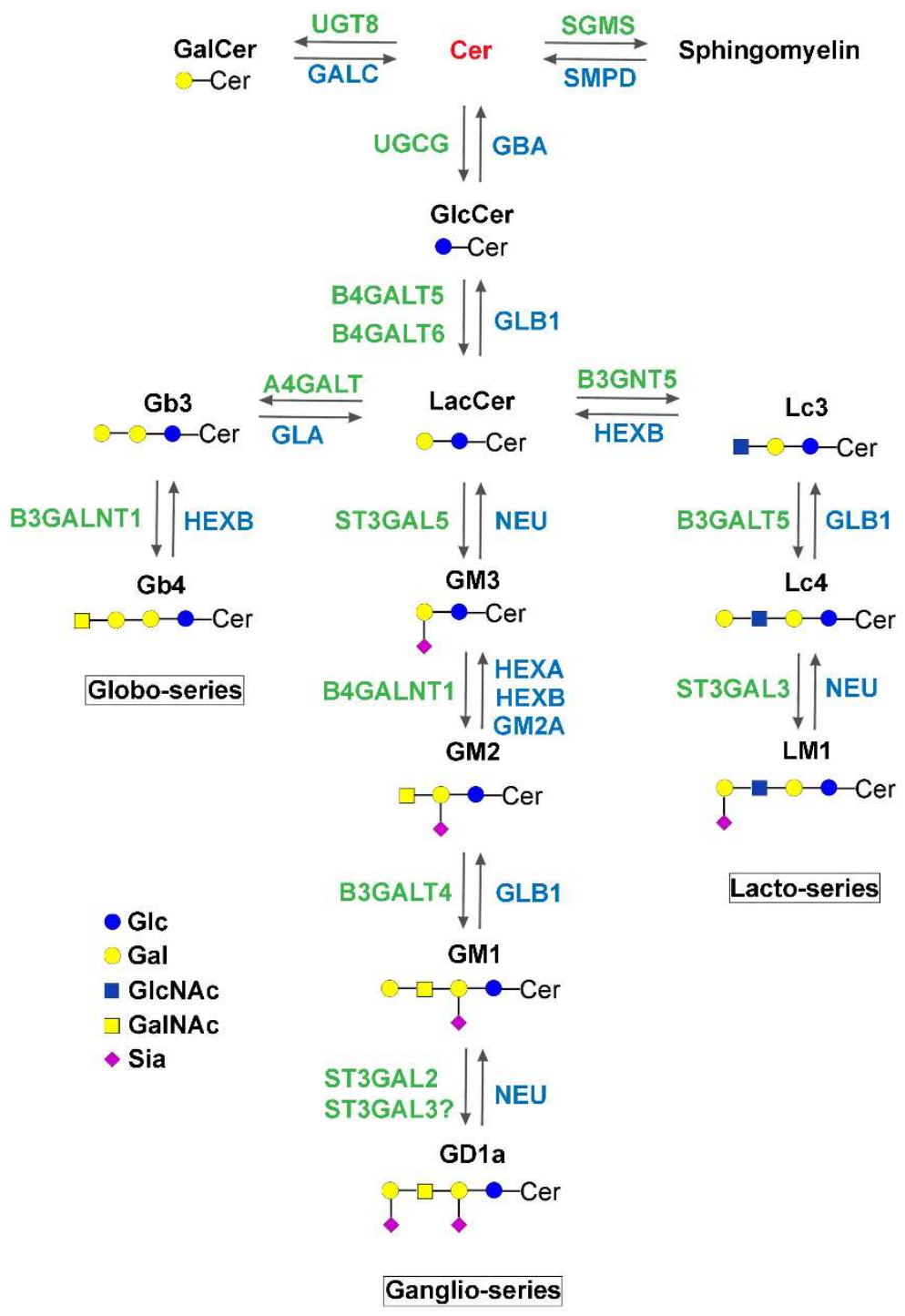

Figure 2. Biosynthesis and degradation of complex glycosphingolipids. Monosaccharides are depicted according to the current representation: Glc, glucose; Gal, galactose; GlcNAc, N-acetylglucosamine; GalNAc, N-acetylgalactosamine; Sia, sialic acid. Enzyme symbols are according to the HUGO nomenclature (see Table 3; Table 2 for enzyme details). UGT8, GalCer synthase; GALC, galactocerebrosidase; SGMS, sphingomyelin synthase; SMPD, sphingomyelinase; UGCG, GlcCer synthase; GBA, glucocerebrosidase; B4GALT, $\beta 1$,4-galactosyltransferase; GLB1, $\beta$-galactosidase;

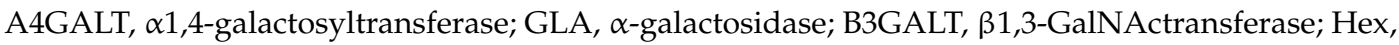
hexosaminidase; B3GNT, $\beta 1,3$-GlcNAc transferase; B3GALT, $\beta 1$,3-galactosyltransferase; ST3GAL, galactoside- $\alpha 2,3$-sialyltransferase; NEU, neuraminidase (sialidase). Lc3, lactotriaosylceramide GlcNAc $\beta 1,3 \mathrm{Gal} \beta 1,4 \mathrm{GlcCer} ; \quad$ Lc4, lactotetraosylceramide; LM1， sialyllactotetraosylceramide, Sia $\alpha 2,3 \mathrm{Gal} \beta 1,3 \mathrm{GlcNAc} \beta 1,3 \mathrm{Gal} \beta 1,4 \mathrm{GlcCer} ; \mathrm{Gb} 3$, globotriaosylceramide Gal $\alpha 1,3 \mathrm{Gal} \beta 1,4 \mathrm{GlcCer}$; Gb4, globotetraosylceramide GalNAc $\beta 1,3 \mathrm{Gal} \alpha 1,3 \mathrm{Gal} \beta 1,4 \mathrm{GlcCer}$.

\section{GBA Variants, GD, PD, and How They Interplay}

GD is a lysosomal storage disorder caused by recessive mutations in the GBA gene, coding the $\beta$-galactosidase responsible for the degradation of GlcCer to glucose and ceramide [39]. Reduced GBA activity leads to the accumulation of GlcCer and/or its immediate by-product glucosylsphingosine (GlcSph), formed by the action of acid ceramidase on GlcCer (Figure 3). GBA is synthesized in the ER as a 536- or 516-amino-acid protein, containing a short signal peptide of 19 or 39 amino acids at the N-terminus that is trimmed soon after translation [40]. The residual 497 amino acid peptide is then 
glycosylated [41] and recognized by the SCARB2 (scavenger receptor class B member 2) system [42]. The GBA/SCARB2 complex [43] experiences traffic through the Golgi apparatus and endocytic vesicles and then reaches the lysosomes, which are the sites of action. In the lysosomes, GBA activity is also controlled by the activator protein saponisin C. Another glucocerebrosidase is coded by the human genome, GBA2, which has a microsomal localization and is not involved in GD but instead is responsible for a form of HSP, reported as HSP46 [28,44] (Table 1). From a clinical point of view, patients suffering GD present two main distinct syndromes [8,27]. Type 1 GD is characterized by the involvement of several visceral organs without that of the central nervous system, while types 2 and 3 present serious neurologic symptoms and are defined as neuronopathic GD. Symptoms of type 1 disease appear in adulthood and classically include anemia, hepatosplenomegaly, bone pain, and other inflammatory signs. The inflammatory effect of GlcCer accumulation was recently proposed to be the consequence of complement C5a activation [45]. However, more recent reports identified patients with type 1 GD developing peripheral polyneuropathy at an older age [33]. Moreover, a subset of patients was recently reported to present mild but distinctive intellectual impairment, suggesting an involvement of the central nervous system $[46,47]$. Conversely, neuronopathic disease is much more severe: early onset of neurologic symptoms includes supranuclear gaze palsy, cognitive impairment (frequently, features of oppositional defiant disorder), seizures, various muscular problems, and even sudden death. Rapid progression of the disease with death in early childhood is characteristic of type 2 disease, while in type 3 the progression is slower. Type 2 and 3 diseases are also suggested to be the more evident forms of a spectrum disease [33]. About 300 different mutations have been reported to affect the GBA gene. Some of them, such as L444P and N370S, are more frequent and account for several cases. There is a wide variety of mutation frequency between ethnicities. For instance, up to 1 in every 15 persons is considered a carrier of a GBA mutation in the Ashkenazi Jewish population, versus 1 in every 100 for others [27,48]. Despite several attempts to find a correlation between individual mutations and the clinical syndrome, none have been firmly established so far, and patients affected by the same mutation present a large variability of symptoms [27,32]. Data of the residual enzyme activity and its potential role as a predictor of disease severity are also contradictory [33,49]. Both the common L444P and N370S variants are associated with a similar strong reduction in enzyme activity, about $80-90 \%$ compared with the wild type enzyme [50]. Conversely, the N370S variant is more frequently associated with the type 1 disease and a mild or very mild phenotype, while the L444P variant is associated with type 3 disease and a severe neuronopathic phenotype in general. Some reports indicate that GBA variants are instable or misfolded proteins, which do not undergo normal intracellular traffic, irrespective of the amount of catalytic activity maintained [39,50], suggesting a role for proteostasis in GD. A very intriguing issue in this field is the epidemiological evidence, established about 10 years ago, that GBA mutations are the major genetic risk factors for the development of PD in elderly people [51]. Such a risk is associated not only with GD but with the carrier status of heterozygous GBA variants, as proven in the family members of GD patients. The molecular mechanism linking GBA mutations to PD appears complex. Experimental evidence indicates that reduced GBA activity and concurrent accumulation of GlcCer takes places in normal aging of the mouse brain [52]. In humans, reduced expression and activity of GBA was found in the substantia nigra of the post-mortem brains of patients suffering from PD, both sporadic and associated with GBA mutations [53]. Pathologically, the hallmark of PD is the presence of Lewy bodies in affected cells, consisting of the accumulation of $\alpha$-synuclein aggregates in the cells. The derangement of $\alpha$-synuclein metabolism in PD is suspected to be the consequence of impaired autophagy and lysosome clearance [50,54]. The interaction between GBA variants, with or without loss of GBA activity, and $\alpha$-synuclein accumulation has been intensively studied in neuronal cultures and in animal models. Deposition of $\alpha$-synuclein aggregates impairs vesicle trafficking [55], which disrupts traffic of GBA and other hydrolases to the lysosomes, favoring further $\alpha$-synuclein accumulation and self-maintenance of the pathogenic process [54]. Accordingly, double transgenic mice heterozygous for a null GBA allele and expressing human $\alpha$-synuclein showed a relevant disruption of dopaminergic neurons 
associated with the accumulation of GlcSph but not GlcCer [56]. Comparable results were found by analyzing post-mortem brains of patients suffering sporadic PD or dementia with Lewy bodies, where the levels of $\alpha$-synuclein were inversely correlated with those of the GBA protein and directly with those of GlcSph [57]. On this basis, it was hypothesized that parallel reduction of GlcCer synthase activity, with concurrent lowering of the GSL levels and, in turn, the GlcCer load into the lysosomes, may prevent such derangement. Studies on GlcCer synthase inhibitors able to pass the blood-brain barrier are in progress as novel therapeutic approaches [58]. In a cellular model of GBA deficiency, obtained by CRISP/Cas9 genome editing of HEK-293 cells, decreased ceramide levels were found to be associated with impaired secretory autophagy and intracellular $\alpha$-synuclein accumulation [59], which is prevented by exogenous ceramide supplement or acid ceramidase inhibition. These results point out that the relative loss of GBA activity and consequent accumulation of GlcCer or its by-product GlcSph, or ceramide depletion, are pathogenic, impairing lysosomal function and autophagy [60] and, in turn, triggering the development of PD. Moreover, GBA deficiency may promote the spread of protein aggregates through extracellular vesicles [61]. On the other hand, other data suggests that GBA activity and GlcCer/GlcSph/ceramide levels are not necessary to determine the increased risk of developing PD. Carriers of the E326K GBA variant, which maintain substantial enzymatic activity, present increased risk of developing PD, although such mutation does not determine GD in the homozygotes [62]. Impaired autophagy due to GBA mutations was suggested to occur and to affect the clearance of damaged mitochondria as a consequence of altered proteostasis [50,63]. In mouse and cellular models carrying the L444P GBA variant, the loss of lysosomal enzyme activity blocks the degradation of autophagic cargos, whereas the variant GBA protein impairs autophagy induction and the priming of damaged mitochondria, indicating a gain of toxic function for the mutant protein. This effect may be attributed to the ER retention of the variant GBA protein, resulting in an unfolded protein response [64]. In a mouse model, overexpression in the striatum of the N370S GBA variant affects $\alpha$-synuclein and, in particular, its secretion through exosomes, while the simple inhibition of enzyme activity by conditurol- $\beta$-epoxide does not [65].

Enzyme replacement and substrate reduction therapies are currently approved and used in clinical practice for the treatment of GD patients suffering visceral symptoms of the disease [66]. They are ineffective in neuronopathic GD because they are unable to cross the blood-brain barrier. In light of the emerging complexity of GD pathogenesis, the above-mentioned mechanisms of disease also provide new potential targets of therapeutic approaches $[66,67]$. In particular, heterogeneity in the clinical outcome between patients harboring the same genotype introduced the concept of genetic modifiers of the disease. They are defined as genes able to alter the clinical phenotype of a disease, modifying the penetrance, expressivity, dominance, or pleiotropy of the causative defect. Several have been identified for GD, some acting directly on the GBA pathway (GBA2, SCARB2, UGCG), and others regulating lysosomal function (TFEB, transcription factor EB) or downstream pathways [68]. Small molecules able to cross the blood-brain barrier are able to increase TFEB activity, inhibit UGCG [58], or restore autophagy [69], representing promising examples of such novel drugs.

\section{Other Diseases of Sphingolipid Metabolism Determining or Predisposing Individuals to Neurodegenerative Disorders}

The growing and converging evidence supporting lysosome involvement in PD and the relevance of GBA variants as the main genetic risk factors for developing the disease have prompted several researchers to study potential connections between other lysosomal diseases and neurodegenerative disorders (data are summarized in Table 1). The first association was proposed between sphingomyelinase SMPD1 variants, causing Niemann-Pick disease types A and B and $\mathrm{PD}$ [70], and received further confirmations suggesting that reduced sphingomyelinase activity led to $\alpha$-synuclein accumulation [71]. Niemann-Pick disease type $C$ is clinically similar to Niemann-Pick disease type $\mathrm{A}$, but is determined by mutations of a different gene (NPDC1, neural proliferation differentiation and control protein 1), coding a protein regulating endocytic transport in late endosomes 
and lysosomes. Interestingly, inhibition of GBA2 improves lysosomal function in fibroblasts from Niemann-Pick disease type $C$ patients [72]. Thus, the question rose as to whether mutations of other genes responsible for known lysosomal storage diseases predispose patients to PD. Analysis of a large whole exome sequencing dataset available for PD [73] suggested the association of the disease with three proteins responsible for lysosomal diseases in addition to GBA and SMPD1. They include ASAH1 (acid ceramidase, causing Farber disease), CLN10 (cathepsin-D, a lysosomal aspartyl proteinase causing neuronal ceroid lipofuscinosis), and SLC17A5 (sialin, causing Salla disease). The latter is involved in the transport of the sialic acid residues released by the action of sialidases on gangliosides and glycoproteins out of lysosomes [74]. Of note, Farber disease is a typical spectrum disease where patients carrying the same mutation present very different clinical features (reviewed in [29]) (Table 1). Neuronal ceroid lipofuscinosis is a neurodegenerative disorder determined by the mutations of at least 13 different genes, all somewhat involved in autophagy [75]. Recent studies on $\alpha$-galactosidase A (GLA) deficiency, causing Fabry disease, an X-linked disorder causing systemic symptoms, have suggested a possible association between GLA mutations and PD or multiple sclerosis [38,76]. Moreover, GLA activity was reported to be lower in PD cases compared to controls [77]. Similarly, galactocerebrosidase (GALC) mutations, causing Krabbe disease, are studied as potentially being related to neurodegeneration/multiple sclerosis and synucleopathies [78-80]. In this regard, lysosphigolipids (Figure 3) formed in the disease, and even in GD, Fabry disease, Niemann-Pick disease, and GM1 gangliosidosis (Table 1), were reported to affect endolysosomal transport and $\mathrm{pH}$, leading to the possible formation of $\alpha$-synuclein aggregates $[81,82]$. Signs of Parkinsonism are now considered to be detectable in various inherited metabolic disorders in addition to GD and Niemann Pick disease [83]. Recent studies highlight the potential link between PD and sphingolipids, particularly gangliosides. They were found to promote $\alpha$-synuclein aggregation in vitro [84]. In cellular models, accumulation of gangliosides due to reduced activity of GBA variants prevented the formation of stable $\alpha$-synuclein tetramers, and pharmacologic (miglustat) inhibition of GSL biosynthesis restored $\alpha$-synuclein stabilization [85]. Reduced expression of galactosyltransferase B3GALT4 and sialyltransferase ST3GAL2, as detected by in situ hybridization, was found to occur specifically in neuromelanin producing neurons of the brains of PD patients [86]. Plasma levels of GM3 were found to be increased in PD patients [87].

It is also interesting to consider the data now available from inherited diseases of sphingolipid metabolism very recently reported (Tables 2 and 3). In the defects of serine palmitoyl transferases SPTLC1-2 and dihydroceramide desaturase DEGS1, causing forms of hereditary sensory neuropathy type 1 and hypomyelinating leukodystrophy, respectively, the presence of potentially toxic compounds is suspected to be involved in the disease pathogenesis. In particular, deoxysphingolipids formed by SPTLC1-2 variants were found to exert mitochondrial toxicity [10], and increased amounts of reactive oxygen species (ROS) were detected in fibroblasts from patients carrying DEGS1 variants. Interestingly, pharmacological inhibition of CERS prevents ROS accumulation [21].

Heterozygous variants of sphingomyelin synthase SGMS2, an enzyme coding a plasma membrane form of sphingomyelin synthase, were found associated with the clinical picture of Osteoporosis with Skeletal Dysplasia. Interestingly, the main clinical signs are restricted to the bones, but a spectrum of mild or very mild neurologic symptoms were detected. Disease severity appeared dependent on mislocalization of enzyme variants more than on levels of residual activity [23].

Together, these data suggest that sphingolipid metabolism interacts with cellular homeostasis through several mechanisms that can be affected by enzyme mutations, as recapitulated by the ability of GBA variants to determine a spectrum disease, including neurodegenerative disorders such as PD. 


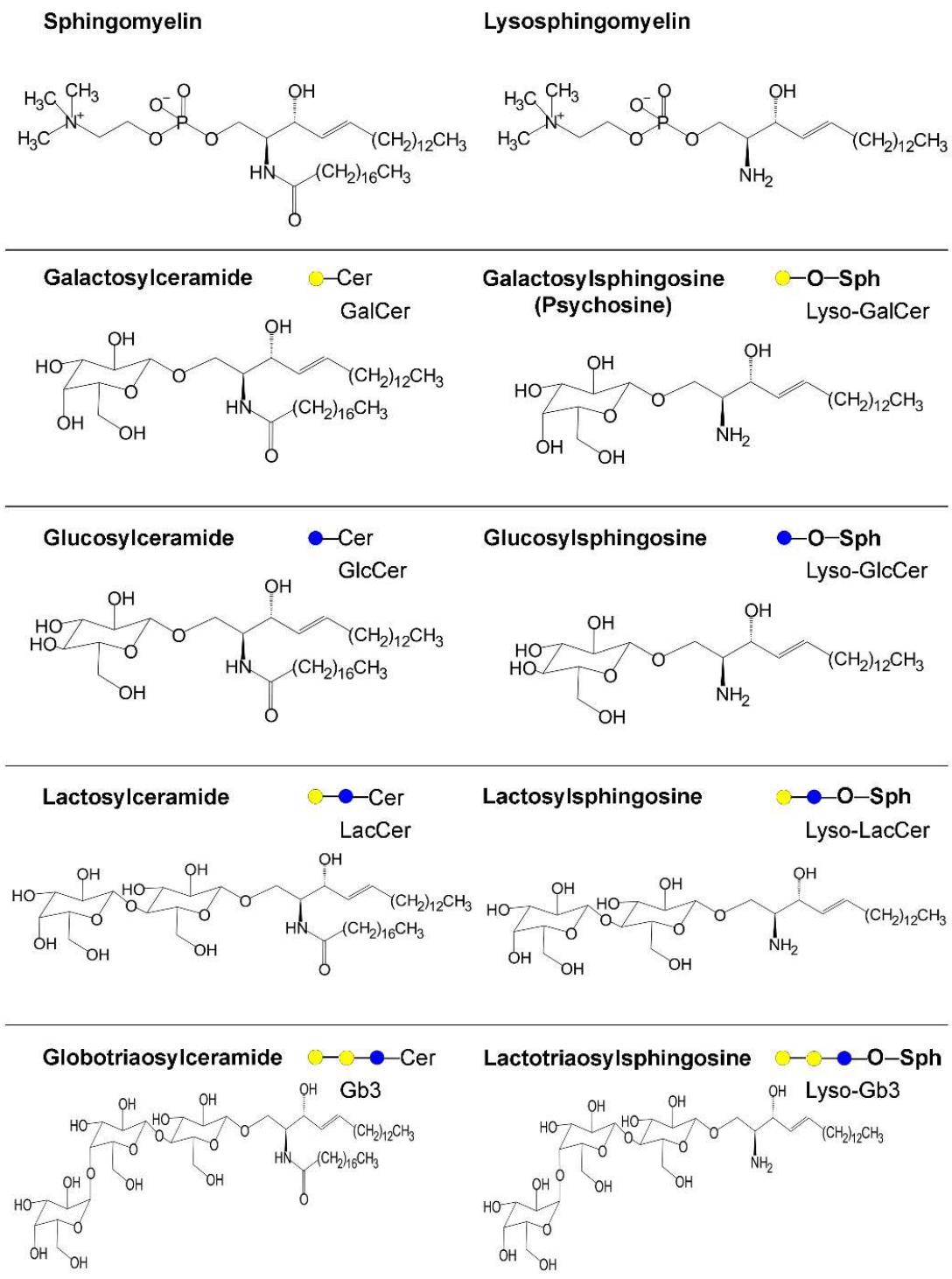

Figure 3. Structure of lysosphingolipids and related compounds. Lysosphingolipds are complex sphingolipids deacylated by the action of acid ceramidase on the corresponding compounds accumulated because of an inborn error of metabolism. Sph, sphingosine. For simplicity, only stearic acid is depicted as the acyl chain, but longer fatty acids are also frequently present.

\section{Specific Diseases of Ganglioside Biosynthesis Determining Neurodegenerative Disorders}

\subsection{GM2 Synthase Deficiency (B4GALNT1-CDG), HSP26, and Other HSPS}

B4GALNT1 is the enzyme necessary to extend all ganglio-series gangliosides [88,89] (Figure 2). Consequently, its impairment leads to a lack of complex gangliosides and accumulation of GM3 and GD3. Twelve pathogenic variants of the gene have been reported so far in 12 families, involving 38 individuals, all showing a form of complex HSP previously referred to as HSP26 [90-92]. The syndrome is characterized by late onset of motor impairment of the legs accompanied by mild to moderate cognitive impairment, sometimes associated with psychiatric illness and/or non-neurological symptoms such as pes cavus or hypogonadism in males (Table 2). Very recently [93], it has been reported that nine out of 11 tested mutations lead to a complete loss of enzyme activity, while two variants (R300C and R228*) maintain a small but detectable residual activity in vitro. Three variants appeared not detectable by western blot, while the other eight were found to be correctly localized to the Golgi apparatus by confocal microscopy, suggesting that the loss of function is the main pathogenic event. This hypothesis is also supported by the evidence that b4galnt1 $\mathrm{KO}$ mice present a similar 
phenotype [94], although in some but not all cases [95]. However, HSP is due to the defect of a plethora of different genes [34]. Two of them directly involve sphingolipid metabolism in addition to B4GALNT1: GBA2, responsible for HSP46 [28], and FA2H, involved in HSP35 [96] and coding for fatty acid 2-hydroxylase [97]. Interestingly, HSP11 is due to the loss of function of spatacsin, a product of the SPG11 gene, which is involved in lysosome membrane recycling. In the spg11 KO mouse model [98], loss of spatacsin impairs ganglioside clearance from the lysosome and determines the accumulation of autophagy markers. In addition, neurodegeneration was stimulated by the accumulation of gangliosides in cultured neurons and was prevented by miglustat. The same authors were also able to reduce motor impairment by inhibiting ganglioside biosynthesis in the HSP11 zebrafish model.

\subsection{GM3 Synthase Deficiency (ST3GAL5-CDG)}

ST3GAL5 displays unique GM3 synthase activity, being responsible for the biosynthesis of ganglio-series gangliosides of the $\mathrm{a}-, \mathrm{b}-$, and c-series, with the exception of 0 -series gangliosides, such as GM1b and GD1 $\alpha$ [99] (Figure 2). Five different pathogenic mutations have been reported so far, all causing a very severe syndrome characterized by normal pregnancy and delivery but early onset of neurological symptoms including drug-resistant epilepsy, failure to thrive, and impaired hearing and vision. Growth delay and progressive regression occur, giving rise to deafness, blindness, and general motor and cognitive impairment $[25,100]$. While the original description of a few families suggested a potential different degree of pathogenicity between mutations [101-103], a recent survey of several cases affected by the same R288* non-sense mutation indicated the opposite [104]. Some of these patients lack clinical seizures or were initially able to crawl, as originally reported only for two siblings carrying the compound C195S/G201A mutations [103]. Accordingly, we have recently shown that all reported mutations abolish any detectable enzyme activity, without differences between the single mutations [100]. Moreover, we also found a normal localization of the variant ST3GAL5s. Altogether, this data is in agreement with the current hypothesis that the total absence of gangliosides is responsible for the general lack of neuron homeostasis, leading to inflammation and, consequently, loss of several functions [105]. However, many patients present mildly elevated blood lactate and their cells have an impaired respiratory chain function $[25,100]$. In this context, the hypothesis that impaired autophagy and, in particular, mitophagy may be involved in the disease pathogenesis should be kept in mind. The enormous distance between the devastating human syndrome and the very mild $\mathrm{KO}$ mouse model $[106,107]$ corroborates such a suggestion.

\subsection{ST3GAL3-CDG, Non-Syndromic Intellectual Disability and West Syndrome}

ST3GAL3 is considered the enzyme responsible for the $\alpha 2,3$ sialylation of galactose preferentially $\beta 1,3$ linked to GlcNAc in several glycoconjugates, including glycoproteins carrying both $\mathrm{N}$ - and Oglycans and GSLs of the lacto-series [108,109]. Data obtained in vitro with the mouse enzyme suggested a strong preference for the Gal $\beta 1,3 \mathrm{GlcNAc}$ acceptor sequence [110], ruling out the ability to use the Gal $\beta 1,3 \mathrm{GalNAc}$ sequence, including ganglio-series gangliosides. Conversely, double st3gal2/st3gal3 $\mathrm{KO}$ mice exhibited substantial loss of GD1a and GT1b gangliosides in their brain, not found in single st3gal2 KO animals, suggesting the ability of the enzyme to use the Galß1,3GalNAc sequence of GSLs in vivo [111]. Detailed data are not available for the human enzyme, which is considered involved in the $\alpha 2,3$ sialylation of the Gal $\beta 1,3 \mathrm{GlcNAc}$ sequence necessary for constructing the tetrasaccharide epitope of the CA19.9 antigen [112], an adhesion molecule potentially involved in cancer $[113,114]$.

Two pathogenic variants of ST3GAL3 were found in adult members of two families reported to suffer from non-syndromic autosomal recessive intellectual disability [115]. The A13N variant appeared to be associated with preserved enzymatic activity in vitro and even only partial retention of the protein in the ER.

Conversely, the other mutation, N370T, was found to determine total loss of enzymatic activity together with substantial retention in the ER. Further, a third mutation (A320P) was reported in four infants from a consanguineous family that were diagnosed with West syndrome, evolved to 
Lennox-Gestaut syndrome [35], which are age-dependent epileptic encephalopathic syndromes defined by a specific electroencephalography pattern and associated with developmental arrest or regression. Such a mutation provided a complete loss of enzymatic activity and impaired protein localization [116].

Recently, neurons differentiated from iPSc cells obtained from fibroblasts carrying the A320P mutation [116] were studied in order to find the glycoproteins lacking sialyl- $\alpha 2,3$ residues, as assessed by Maackia amurensis labeling. A defect in a single $80-\mathrm{kDa}$ glycoprotein was detected in differentiated cortical neurons, together with altered adhesion properties. In the st3gal3 KO mouse model of the disease, the animals lack neurologic symptoms, presenting only mild immunologic anomalies $[117,118]$. In this case, retention in the ER of the variants suggests that they could be misfolded, irrespective of the catalytic activity maintained, and this would be compatible with a pathogenic role of altered proteostasis, irrespective of the lack of sialylation, on either glycoproteins or glycosphingolipids.

\section{Conclusions}

Recent studies on the GD/PD relationship demonstrate that GBA variants predispose individuals to PD through molecular mechanisms that have the potential to operate in other disorders affecting sphingolipid metabolism, leading in turn to neurodegeneration.

One such mechanism depends on the amounts of individual molecules accumulated. It has been well proven in the case of the inflammatory role played by GlcCer through the activation of complement in the tissues affected by type 1 GD [45]. This is also potentially relevant in conditions where gene mutations predispose individuals to the accumulation of non-physiologic by-products, such as lysosphingolipids in several diseases. (Table 1), deoxysphingolipids in hereditary sensory neuropathy type 1 , and $\Delta 14$-cis sphingolipids in defective desaturase activity (Table 3). Similarly, a direct pathogenic effect is possibly due to the lack of specific products in the diseases affecting biosynthetic enzymes, as typically seen in ST3GAL5 deficiency.

Another relevant mechanism suggested by the GBA/PD relationship involves the traffic of vesicles towards lysosomes, affecting autophagy. The peculiar role of autophagy in the survival of neurons is well known, as well as the pathogenic role of its impairment in neurodegeneration [119]. In PD, $\alpha$-synuclein accumulation appears strongly dependent on autophagy, as detailed in the section above. Sphingolipid metabolism strongly interplays with neuronal autophagy, with particular relevance of gangliosides, ceramide, SM, S1P, and GlcCer. Autophagy is impaired by increased GlcCer and SM levels, as determined by GBA and sphingomyelinase SMPD1 deficits, but stimulated by increased ceramide levels (reviewed in [120]) or impaired by reduced levels [59]. Some HSPs are due to impaired sphingolipid metabolism, others to defective mitochondrial proteins, and others to gene mutations that code proteins involved in organelle trafficking and shape [34]. One of the latter, spastin, is considered particularly relevant in the disease pathogenesis suggesting that toxic gain-of-function mechanisms operate in a context of a nervous system made vulnerable by haploinsufficiency [121]. A reasonable hypothesis is that any imbalance between the amounts of individual sphingolipids may impair endocytic trafficking, affecting cargo load or autophagy directly, as proven for GBA variants. In this regard, it is important to note that some models revealed specific impairment of mitophagy in PD [64]. In ST3GAL5-CDG, the lack of ganglio-series gangliosides is probably accompanied by the accumulation of globosides, and mitochondrial defects are present, sometimes reported to misdirect the diagnosis [122], although brain mitochondria lack gangliosides [123]; we speculate that impaired mitophagy may occur in the disease as suggested for lysosomal storage diseases [124].

Finally, GBA variants affect cell homeostasis through altered proteostasis due to ER stress or other consequences of protein misfolding $[39,48,54]$. In ST3GAL3-CDG, protein variants were reported to be improperly localized and partially retained in the ER.

A growing number of pharmacologic inhibitors of sphingolipid metabolism are available and studied as drugs potentially suitable in human diseases [125]. Once those able to cross the blood-brain barrier are selected, it will be possible in the future to use them to target the pathogenic mechanisms of some neurodegenerative disorders, possibly in association with the substances potentially able to affect lysosomal function, autophagy, and proteostasis $[68,69,126]$. 
Table 1. Enzymes involved in sphingolipid degradation and recycling.

\begin{tabular}{|c|c|c|c|c|c|c|}
\hline Enzyme & Hugo Symbol & Subcellular Site & Disease & Main Clinical Features & Biochemical Features & Ref \\
\hline Acid ceramidase & ASAH1 & Lysosome & $\begin{array}{l}\text { Farber disease and } \\
\text { spinal muscular } \\
\text { atrophy with } \\
\text { progressive } \\
\text { myoclonic epilepsy }\end{array}$ & $\begin{array}{l}\text { Typical spectrum disease varying from } \\
\text { the classic triad of subcutaneous } \\
\text { nodules, joint contractures, and hoarse } \\
\text { voice to moderate or severe forms } \\
\text { involving hematopoietic, } \\
\text { gastrointestinal, respiratory, and } \\
\text { neurologic symptoms, including } \\
\text { seizures; developmental delay and } \\
\text { death in the early childhood. }\end{array}$ & $\begin{array}{l}\text { The same Y137C mutation } \\
\text { provided very mild phenotype in } \\
\text { a patient and severe neurologic } \\
\text { phenotype in another. Two SNPs } \\
\text { are associated with schizophrenia. } \\
\text { Residual activity }>5 \% \text { is } \\
\text { associated with survival. } \\
\text { Candidate risk factor for } \\
\text { Parkinson's disease (PD). }\end{array}$ & {$[29,73,127]$} \\
\hline Neutral ceramidase & ASAH2 & Plasma membrane & \multirow{3}{*}{ None reported } & $\begin{array}{l}\text { Main expression in the small intestine } \\
\text { and colon, probable role in digestion. }\end{array}$ & & [128] \\
\hline \multirow[b]{3}{*}{ Alkaline ceramidases } & ACER1 & $\begin{array}{l}\text { Endoplasmic } \\
\text { reticulum (ER) }\end{array}$ & & Main expression in the skin. & & [129] \\
\hline & ACER2 & Golgi apparatus & & & & \\
\hline & ACER3 & $\begin{array}{l}\text { ER and Golgi } \\
\text { apparatus }\end{array}$ & $\begin{array}{l}\text { Progressive } \\
\text { leukodystrophy }\end{array}$ & $\begin{array}{l}\text { Developmental regression at } 6-13 \\
\text { months, starting with peripheral } \\
\text { neuropathy and leading to severe } \\
\text { dysmorphic facial feature and } \\
\text { psychomotor impairment, requiring } \\
\text { mechanical ventilation. }\end{array}$ & $\begin{array}{l}\text { Plasma accumulation of } \\
\text { ceramides, dihydroceramides, } \\
\text { glucosylceramide (GlcCer), and } \\
\text { lactosylceramide (LacCer). } \\
\text { Increased blood lactate levels. }\end{array}$ & {$[30]$} \\
\hline \multirow[t]{2}{*}{ Sphingosine kinases } & SPHK1 & $\begin{array}{l}\text { Plasma membrane } \\
\text { (main) }\end{array}$ & \multirow[t]{2}{*}{ None reported } & & & \multirow[t]{2}{*}{ [130] } \\
\hline & SPHK2 & ER (main) & & & & \\
\hline Sphingosine lyase & SGPL1 & ER & $\begin{array}{c}\text { Syndromic } \\
\text { steroid-resistant } \\
\text { nephrotic syndrome }\end{array}$ & $\begin{array}{l}\text { Steroid-resistant nephrotic syndrome } \\
\text { with facultative ichthyosis, adrenal } \\
\text { insufficiency, immunodeficiency, and } \\
\text { neurological defects. }\end{array}$ & $\begin{array}{l}\text { Reduced activity and protein } \\
\text { mislocalization are frequent } \\
\text { between mutations. Ceramides } \\
\text { are elevated in the conditioned } \\
\text { culture medium of patient } \\
\text { fibroblasts. }\end{array}$ & [131] \\
\hline Galacto-cerebrosidase & GALC & Lysosome & Krabbe disease & $\begin{array}{l}\text { Infantile onset (within } 6 \text { months). } \\
\text { Increased irritability, spasticity, } \\
\text { developmental delay along with } \\
\text { unexplained fever, blindness, and } \\
\text { deafness. Severe motor and mental } \\
\text { deterioration. }\end{array}$ & $\begin{array}{l}\text { Poor genotype-phenotype } \\
\text { relationship. } \\
\text { Galactosyl-sphingosine } \\
\text { (psychosine) accumulates, } \\
\text { affecting endolysosomal transport } \\
\text { and pH. Aggregated forms of } \\
\alpha \text {-synuclein reported. }\end{array}$ & {$[37,49,79,91]$} \\
\hline
\end{tabular}


Table 1. Cont.

\begin{tabular}{|c|c|c|c|c|c|c|}
\hline Enzyme & Hugo Symbol & Subcellular Site & Disease & Main Clinical Features & Biochemical Features & Ref \\
\hline \multirow[t]{2}{*}{ Gluco-cerebrosidases } & GBA & Lysosome & Gaucher disease & $\begin{array}{l}\text { Type } 1 \text { disease classically includes } \\
\text { inflammatory signs in visceral organs } \\
\text { that appear in adulthood; types } 2 \text { and } 3 \\
\text { are instead neuronopathic, with early } \\
\text { onset and progression at different rates. } \\
\text { Recently proposed to be a spectrum } \\
\text { disease. Main genetic risk factor for PD } \\
\text { even in heterozygous carriers (see } \\
\text { details in the text). }\end{array}$ & $\begin{array}{l}\text { Poor genotype-phenotype } \\
\text { relationship. GlcCer and } \\
\text { glucosylsphingosine accumulate, } \\
\text { affecting vesicle traffic and } \\
\text { autophagy including mitophagy, } \\
\text { which are also impaired by } \\
\text { altered proteostasis. Strong } \\
\text { evidence that glucocerebrosidase } \\
\text { (GBA) variants affect } \alpha \text {-synuclein } \\
\text { accumulation (see details in } \\
\text { the text). }\end{array}$ & {$[27,33,50,54,57]$} \\
\hline & GBA2 & Microsomes & $\begin{array}{c}\text { HSP46/Cerebellar } \\
\text { ataxia with late-onset } \\
\text { spasticity }\end{array}$ & $\begin{array}{l}\text { Early onset of motor impairment with } \\
\text { mental retardation, cataract, and } \\
\text { hypogonadism in males. MRI: cerebellar } \\
\text { and corpus callosum atrophy. }\end{array}$ & $\begin{array}{l}\text { Loss of enzymatic activity in } \\
\text { almost all known mutations. } \\
\text { Inhibition of activity in fibroblasts } \\
\text { from Niemann-Pick patients } \\
\text { restores endolysosomal pH. }\end{array}$ & {$[28,44,72]$} \\
\hline$\beta$-galactosidase & GLB1 & Lysosome & GM1 gangliosidosis & $\begin{array}{l}\text { Infantile form: early onset and rapid } \\
\text { progressive psychomotor deterioration, } \\
\text { skeletal abnormalities, visceromegaly, } \\
\text { and death. Juvenile and adult } \\
\text { phenotypes characterized by slowly } \\
\text { progressive neurological degeneration } \\
\text { and mild skeletal changes. }\end{array}$ & $\begin{array}{l}\text { Poor genotype-phenotype } \\
\text { correlation. GM1, LacCer, and } \\
\text { lactosylsphingosine accumulate } \\
\text { causing impairment of } \\
\text { endolysosomal transport and pH, } \\
\text { autophagy, and mitochondrial } \\
\text { function). ER stress detected. }\end{array}$ & {$[81,99]$} \\
\hline Hexosaminidase A & HEXA & Lysosome & Tay-Sachs disease & $\begin{array}{l}\text { Infantile form: early onset of } \\
\text { neurodevelopmental dysfunctions, } \\
\text { hypotonia and eye movement } \\
\text { abnormalities. Progression includes } \\
\text { dysphagia, seizures, macrocephaly, and } \\
\text { death until age } 3.5 \text { years. } \\
\text { Juvenile onset includes ataxia, } \\
\text { dysarthria, dysphagia, progressive } \\
\text { hypotonia, seizures, and death until } 15 \\
\text { years of age. }\end{array}$ & & [99] \\
\hline Hexosaminidase B & HEXB & Lysosome & Sandhoff disease & $\begin{array}{l}\text { Juvenile onset form: reduced attention, } \\
\text { weakness, hypotonia, and progressive } \\
\text { psychomotor impairment. } \\
\text { Adult-onset form: milder phenotype } \\
\text { due to residual enzymatic activity. } \\
\text { Muscle weakness and motor symptoms. }\end{array}$ & $\begin{array}{l}\text { GM2, asialo-GM2, and globoside } \\
\text { accumulate. Deposits of } \\
\alpha \text {-synuclein reported. }\end{array}$ & {$[49,99]$} \\
\hline
\end{tabular}


Table 1. Cont.

\begin{tabular}{|c|c|c|c|c|c|c|}
\hline Enzyme & Hugo Symbol & Subcellular Site & Disease & Main Clinical Features & Biochemical Features & Ref \\
\hline GM2 activator & GM2A & Lysosome & GM2 gangliosidosis & Similar to Tay-Sachs disease. & & [99] \\
\hline$\alpha$-galactosidase & GLA & Lysosome & Fabry disease & $\begin{array}{l}\text { X-linked recessive, phenotypes from } \\
\text { healthy to severe in women, severe to } \\
\text { fatal in men. Various organs potentially } \\
\text { involved, including peripheral and } \\
\text { central nervous system. Cardiovascular } \\
\text { involvement is frequent and at high risk } \\
\text { for stroke and arrhythmias. }\end{array}$ & $\begin{array}{l}\text { Globotriaosylceramide and } \\
\text { globotriaosylsphingosine } \\
\text { accumulate. Activity of } \\
\text { respiratory chain enzymes } \\
\text { reduced, protein trafficking and } \\
\text { sorting altered, } \\
\text { autophagy-lysosome pathway } \\
\text { dysregulated. Impaired } \\
\alpha \text {-synuclein degradation. }\end{array}$ & {$[38,76,132$} \\
\hline Acid sphingomyelinase & SMPD1 & $\begin{array}{l}\text { Lysosome and } \\
\text { secretory }\end{array}$ & $\begin{array}{c}\text { Niemann-Pick } \\
\text { disease types A and B }\end{array}$ & $\begin{array}{l}\text { The gene is paternally imprinted. } \\
\text { Type A: acute, early onset with failure to } \\
\text { thrive and hepatosplenomegaly. Rapid } \\
\text { and progressive neurodegenerative } \\
\text { course, hypothonia and death until age } \\
\text { of } 3 \text { years. Cherry-red spot in the macula. } \\
\text { Type B: chronic, no neurologic signs. } \\
\text { Hepato-splenomegaly and signs of liver } \\
\text { failure. Impaired pulmonary function. } \\
\text { High levels of serum triglycerides and } \\
\text { LDL-cholesterol, low levels of } \\
\text { HDL-cholesterol. Reddish brown or } \\
\text { cherry red spot in the macula. SMPD1 } \\
\text { variants are confirmed risk factor for PD. }\end{array}$ & $\begin{array}{l}\text { Good genotype-phenotype } \\
\text { correlation. Sphingomyelin and } \\
\text { lysosphingomyelin } \\
\text { (sphingosine-phosphocoline) } \\
\text { accumulate. Increased levels of } \\
\text { cholesterol, GlcCer, LacCer, and } \\
\text { gangliosides. Decreased activity } \\
\text { levels led to } \alpha \text {-synuclein } \\
\text { accumulation. }\end{array}$ & {$[22,36]$} \\
\hline \multirow{4}{*}{$\begin{array}{c}\text { Neutral } \\
\text { sphingomyelinases }\end{array}$} & SMPD2 & Plasma membrane & \multirow{4}{*}{ None reported } & & & \multirow{4}{*}{ [22] } \\
\hline & SMPD3 & $\begin{array}{l}\text { ER, Golgi apparatus, } \\
\text { and nucleus }\end{array}$ & & & & \\
\hline & SMPD4 & $\begin{array}{c}\text { ER and Golgi } \\
\text { apparatus }\end{array}$ & & & & \\
\hline & SMPD5 & $\begin{array}{c}\text { Mitochondria and } \\
\text { ER }\end{array}$ & & & & \\
\hline
\end{tabular}


Table 2. Golgi apparatus resident enzyme involved in the biosynthesis of complex sphingolipids. Note that sphingomyelin synthase SGMS2 resides in the plasma membrane.

\begin{tabular}{|c|c|c|c|c|c|c|}
\hline Enzyme & Hugo Symbol & Disease & Inheritance & Main Clinical Features & Biochemical Features & Ref. \\
\hline \multirow{2}{*}{ Sphingomyelin synthases } & SGMS1 & None reported & & & & [22] \\
\hline & $\begin{array}{l}\text { SGMS2 (plasma } \\
\text { membrane } \\
\text { resident) }\end{array}$ & $\begin{array}{l}\text { Osteoporosis with } \\
\text { skeletal dysplasia }\end{array}$ & Autosomal dominant & $\begin{array}{l}\text { Minor neurologic signs detectable in } \\
\text { some cases. Childhood onset } \\
\text { osteoporosis with or without cranial } \\
\text { sclerosis, neonatal fractures, short } \\
\text { stature, and spondylometaphyseal } \\
\text { dysplasia. }\end{array}$ & $\begin{array}{l}\text { Variants are frequently mislocalized } \\
\text { or retained in the ER; catalytic } \\
\text { activity maintained by some } \\
\text { variants. }\end{array}$ & [23] \\
\hline Glucosylceramide synthase & UGCG & Congenital ichthyosis & Autosomal recessive & $\begin{array}{l}\text { Normal growth parameters at birth, but } \\
\text { covered with a collodion membrane; } \\
\text { death at age } 2 \text { weeks because of severe } \\
\text { hypernatremic anuric renal failure. }\end{array}$ & $\begin{array}{l}\text { Phenotype similar to that of the } \\
\text { keratinocyte-conditional KO mouse. }\end{array}$ & [24] \\
\hline $\begin{array}{l}\text { UDP-Gal: GlcCer } \beta 1,4- \\
\text { galactosyltransferase }\end{array}$ & B4GALT6 & \multirow{3}{*}{ None reported } & & & \multicolumn{2}{|l|}{ Synthesizes lactosylceramide. } \\
\hline $\begin{array}{l}\text { UDP-Gal: } \\
\text { lactosylceramide } \alpha-1,4- \\
\text { galactosyl-transferase }\end{array}$ & A4GALT & & & & \multicolumn{2}{|l|}{ Synthesizes globotriosyl ceramide. } \\
\hline $\begin{array}{c}\text { UDP-GlcNAc: } \\
\text { lactosylceramide } \\
\beta-1,4-G l c N A c \text { transferase }\end{array}$ & B3GNT5 & & & & \multicolumn{2}{|l|}{$\begin{array}{l}\text { Synthesizes lacto-N-triosyl } \\
\text { ceramide. }\end{array}$} \\
\hline GM3 synthase & ST3GAL5 & ST3GAL5-CDG & Autosomal recessive & $\begin{array}{l}\text { Normal at birth, early onset severe } \\
\text { neurological signs. Failure to thrive, } \\
\text { regression, severe hearing, visual, motor, } \\
\text { and cognitive impairment (see details in } \\
\text { the text). }\end{array}$ & $\begin{array}{l}\text { Mitochondrial defects in patients. } \\
\text { Globosides accumulate in human } \\
\text { fibroblasts. }\end{array}$ & {$[25,100-104]$} \\
\hline GM2/GD2/GA2 synthase & B4GALNT1 & $\begin{array}{l}\text { Hereditary spastic } \\
\text { paraplegia 26 } \\
\text { (B4GALNT1-CDG) }\end{array}$ & Autosomal recessive & $\begin{array}{l}\text { Late onset motor impairment of the legs } \\
\text { accompanied by mild to moderate } \\
\text { cognitive impairment, sometimes } \\
\text { associated with psychiatric illness } \\
\text { and/or non-neurological symptoms (see } \\
\text { details in the text). }\end{array}$ & $\begin{array}{l}\text { GM3 and GD3 accumulate in vivo } \\
\text { and in vitro models. }\end{array}$ & [90-92] \\
\hline $\begin{array}{l}\text { UDP-Gal: GM2/GD2/GA2 } \\
\beta 1,3 \text {-galactosyltransferase }\end{array}$ & B3GALT4 & None reported & & & $\begin{array}{l}\text { Synthesizes gangliosides GM1, } \\
\text { GD1a, and GD1b. }\end{array}$ & \\
\hline $\begin{array}{l}\text { CMP-Sial: GlcNAc } \beta 1,3(4) \\
\text { sialyltransferase }\end{array}$ & ST3GAL3 & $\begin{array}{c}\text { Non syndromic } \\
\text { autosomal recessive } \\
\text { intellectual } \\
\text { disability/West syndrome }\end{array}$ & Autosomal recessive & $\begin{array}{l}\text { Only intellectual disability reported } \\
\text { when diagnosed in adults, West } \\
\text { syndrome when diagnosed in early } \\
\text { childhood (see details in the text). }\end{array}$ & $\begin{array}{l}\text { ER retention frequent in variants, } \\
\text { enzyme activity maintained in one } \\
\text { variant. }\end{array}$ & {$[35,115,116]$} \\
\hline
\end{tabular}


Table 3. Endoplasmic reticulum resident enzymes involved in the initial biosynthesis of sphingolipids.

\begin{tabular}{|c|c|c|c|c|c|c|}
\hline Enzyme & Hugo Symbol & Disease & Inheritance & Main Clinical Features & Biochemical Features & Ref. \\
\hline \multirow[t]{3}{*}{$\begin{array}{l}\text { Serine palmitoyl } \\
\text { transferases }\end{array}$} & SPTLC1 & \multirow[t]{2}{*}{$\begin{array}{l}\text { Hereditary sensory } \\
\text { neuropathy (Type 1) }\end{array}$} & \multirow[t]{2}{*}{$\begin{array}{c}\text { Autosomal } \\
\text { dominant }\end{array}$} & \multirow{2}{*}{$\begin{array}{l}\text { Onset of sensory impairment spanning the second } \\
\text { to fifth decades, frequent motor impairment and } \\
\text { burning pain episodes; distal to proximal } \\
\text { progression. Mutations of either one or two } \\
\text { subunits determine identical clinical phenotypes. }\end{array}$} & \multirow{2}{*}{$\begin{array}{l}\text { Alanine and glycine used instead of } \\
\text { serine producing deoxysphinganine } \\
\text { and deoxyceramide, which have } \\
\text { mitochondrial toxicity in vitro. }\end{array}$} & \multirow[t]{2}{*}[9,10]{} \\
\hline & SPTLC2 & & & & & \\
\hline & SPTLC3 & None reported & & & & \\
\hline $\begin{array}{l}\text { 3-keto-dihydro- } \\
\text { sphingosine reductase }\end{array}$ & KDSR & $\begin{array}{l}\text { Erythrokeratoderma or } \\
\text { ichtyosis with anemia and } \\
\text { thrombocytopenia }\end{array}$ & $\begin{array}{l}\text { Autosomal } \\
\text { recessive }\end{array}$ & $\begin{array}{l}\text { No neurologic signs. Heterogeneous skin and } \\
\text { hematologic symptoms; spontaneous remission } \\
\text { with age in some cases. }\end{array}$ & $\begin{array}{l}\text { Retinoic acid therapy effective, } \\
\text { probably stimulating salvage pathway } \\
\text { from sphingosine. }\end{array}$ & [11-13] \\
\hline \multirow{6}{*}{$\begin{array}{l}\text { Dihydro-ceramide } \\
\text { synthases }\end{array}$} & CERS1 & Myoclonus epilepsy & $\begin{array}{l}\text { Autosomal } \\
\text { recessive }\end{array}$ & $\begin{array}{l}\text { Ataxia at the age of one year, delay in development, } \\
\text { generalized tonic-clonic seizures, action myoclonus } \\
\text { with onset between } 6 \text { and } 16 \text { years of age. Cognitive } \\
\text { deterioration up to dementia.Magnetic resonance } \\
\text { imaging: brainstem atrophy. }\end{array}$ & & {$[14,15]$} \\
\hline & CERS2 & $\begin{array}{l}\text { Progressive myoclonus } \\
\text { epilepsy }\end{array}$ & $\begin{array}{l}27 \mathrm{~kb} \text { heterozygous } \\
\text { deletion }\end{array}$ & $\begin{array}{l}\text { Tonic-clonic seizures prevented by valproic acid, } \\
\text { learning disability, progressive myoclonic epilepsy, } \\
\text { moderate intellectually disability with dysarthria } \\
\text { and ataxia. }\end{array}$ & & [17] \\
\hline & CERS3 & Congenital ichthyosis & $\begin{array}{l}\text { Autosomal } \\
\text { recessive }\end{array}$ & $\begin{array}{l}\text { No neurologic signs. Congenital ichthyosis } \\
\text { characterized by collodion membranes at birth, } \\
\text { generalized scaling of the skin, and mild } \\
\text { erythroderma. }\end{array}$ & $\begin{array}{l}\text { Specific loss of ceramides with acyl } \\
\text { chains from C } 26 \text { up to C } 34 \text { in } \\
\text { keratinocytes. }\end{array}$ & [16] \\
\hline & CERS4 & \multirow{3}{*}{ None reported } & & & & \multirow{3}{*}{ [18] } \\
\hline & CERS5 & & & & & \\
\hline & CERS6 & & & & & \\
\hline \multirow[t]{2}{*}{$\begin{array}{l}\text { Dihydro-ceramide } \\
\text { desaturases }\end{array}$} & DEGS1 & $\begin{array}{l}\text { Hypomyelinating } \\
\text { Leukodystrophy }\end{array}$ & $\begin{array}{l}\text { Autosomal } \\
\text { recessive }\end{array}$ & $\begin{array}{l}\text { Onset at } 0.5-24 \text { months. Failure to thrive, } \\
\text { developmental delay, epilepsy, neurogenic } \\
\text { muscular atrophy, severe motor arrest, } \\
\text { microcephaly, dystonia and severe spasticity. } \\
\text { MRI: hypomyelination, thin white matter, } \\
\text { progressive thalamic and cerebellar atrophy. }\end{array}$ & $\begin{array}{l}\text { Presence of } \Delta 14 \text {-cis sphingolipids; } \\
\text { inhibition of CERS ameliorates } \\
\text { phenotype in zebrafish model, and } \\
\text { reactive oxygen species (ROS) levels in } \\
\text { patient fibroblasts. }\end{array}$ & {$[20,21]$} \\
\hline & DEGS2 & None reported & & Relevant in stratum corneum. & $\begin{array}{l}\text { Involved in the metabolism of } \\
\text { sphingolipid containing } \\
\text { 4-hydroxysphingosine } \\
\text { (phytosphingosine). }\end{array}$ & [19] \\
\hline $\begin{array}{l}\text { SM synthase related } \\
\text { protein }\end{array}$ & SAMD8 & None reported & & & $\begin{array}{l}\text { Involved in the synthesis of ceramide } \\
\text { phosphoethanolamine. }\end{array}$ & [22] \\
\hline GalCer synthase & UGT8 & None reported & & & & \\
\hline
\end{tabular}


Funding: This research was funded by grants from the University of Insubria to Marco Trinchera and from the PhD program in Translational Medicine of the University of Milan supporting Rossella Indellicato. Neither of the authors received funds for covering the costs to publish in open access that were waived.

Acknowledgments: The author wish to thank Riccardo Ghidoni (University of Milan) for helpful suggestions.

Conflicts of Interest: The authors declare no conflict of interest.

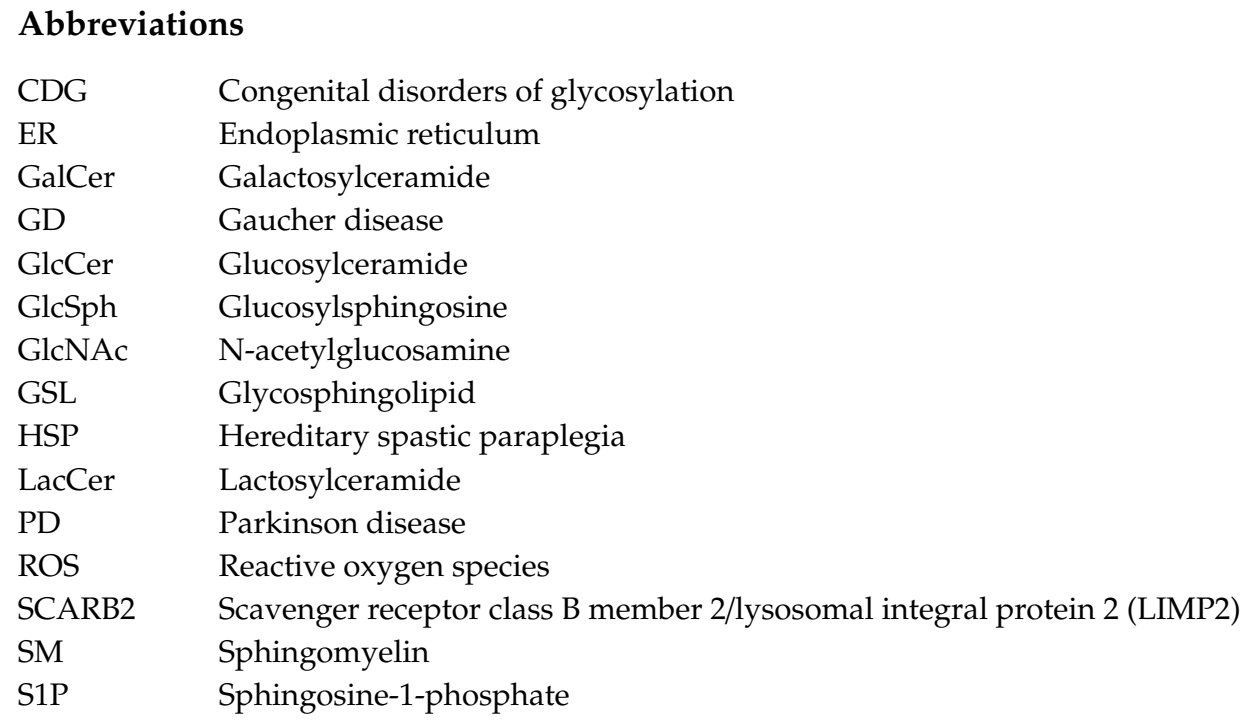

\section{References}

1. Gault, C.R.; Obeid, L.M.; Hannun, Y.A. An overview of sphingolipid metabolism: from synthesis to breakdown. Adv. Exp. Med. Biol. 2010, 688, 1-23.

2. Hannun, Y.A.; Obeid, L.M. Sphingolipids and their metabolism in physiology and disease. Nat. Rev. Mol. Cell Biol. 2018, 19, 175-191. [CrossRef]

3. Chen, Y.; Cao, Y. The sphingomyelin synthase family: proteins, diseases, and inhibitors. Biol. Chem. 2017, 398, 1319-1325. [CrossRef]

4. Hayashi, Y.; Nemoto-Sasaki, Y.; Matsumoto, N.; Hama, K.; Tanikawa, T.; Oka, S.; Saeki, T.; Kumasaka, T.; Koizumi, T.; Arai, S.; et al. Complex formation of sphingomyelin synthase 1 with glucosylceramide synthase increases sphingomyelin and decreases glucosylceramide levels. J. Biol. Chem. 2018, 293, 17505-17522. [CrossRef]

5. Nickel, W.; Brugger, B.; Wieland, F.T. Protein and lipid sorting between the endoplasmic reticulum and the Golgi complex. Seminars Cell Dev. Biol. 1998, 9, 493-501. [CrossRef]

6. Russo, D.; Capolupo, L.; Loomba, J.S.; Sticco, L.; D’Angelo, G. Glycosphingolipid metabolism in cell fate specification. J. Cell Sci. 2018, 131. [CrossRef]

7. Verderio, C.; Gabrielli, M.; Giussani, P. Role of sphingolipids in the biogenesis and biological activity of extracellular vesicles. J. Lipid Res. 2018, 59, 1325-1340. [CrossRef]

8. Platt, F.M.; d’Azzo, A.; Davidson, B.L.; Neufeld, E.F.; Tifft, C.J. Lysosomal storage diseases. Nat. Rev. Dis. Primers 2018, 4, 27. [CrossRef]

9. Bejaoui, K.; Wu, C.; Scheffler, M.D.; Haan, G.; Ashby, P.; Wu, L.; de Jong, P.; Brown, R.H., Jr. SPTLC1 is mutated in hereditary sensory neuropathy, type 1. Nat. Genet. 2001, 27, 261-262. [CrossRef]

10. Wilson, E.R.; Kugathasan, U.; Abramov, A.Y.; Clark, A.J.; Bennett, D.L.H.; Reilly, M.M.; Greensmith, L.; Kalmar, B. Hereditary sensory neuropathy type 1-associated deoxysphingolipids cause neurotoxicity, acute calcium handling abnormalities and mitochondrial dysfunction in vitro. Neu. Dis. 2018, 117, 1-14. [CrossRef]

11. Boyden, L.M.; Vincent, N.G.; Zhou, J.; Hu, R.; Craiglow, B.G.; Bayliss, S.J.; Rosman, I.S.; Lucky, A.W.; Diaz, L.A.; Goldsmith, L.A.; et al. Mutations in KDSR Cause Recessive Progressive Symmetric Erythrokeratoderma. Am.J. Hum. Genet. 2017, 100, 978-984. [CrossRef]

12. Takeichi, T.; Torrelo, A.; Lee, J.Y.W.; Ohno, Y.; Lozano, M.L.; Kihara, A.; Liu, L.; Yasuda, Y.; Ishikawa, J.; Murase, T.; et al. Biallelic Mutations in KDSR Disrupt Ceramide Synthesis and Result in a Spectrum of Keratinization Disorders Associated with Thrombocytopenia. J. Investig. Dermatol. 2017, 137, 2344-2353. [CrossRef] 
13. Bariana, T.K.; Labarque, V.; Heremans, J.; Thys, C.; De Reys, M.; Greene, D.; Jenkins, B.; Grassi, L.; Seyres, D.; Burden, F.; et al. Sphingolipid dysregulation due to lack of functional KDSR impairs proplatelet formation causing thrombocytopenia. Haematologica 2019, 104, 1036-1045. [CrossRef]

14. Vanni, N.; Fruscione, F.; Ferlazzo, E.; Striano, P.; Robbiano, A.; Traverso, M.; Sander, T.; Falace, A.; Gazzerro, E.; Bramanti, P.; et al. Impairment of ceramide synthesis causes a novel progressive myoclonus epilepsy. Ann. Neurol. 2014, 76, 206-212. [CrossRef]

15. Godeiro Junior, C.O.; Vale, T.C.; Afonso, C.O.M.; Kok, F.; Pedroso, J.L.; Barsottini, O.G. Progressive Myoclonic Epilepsy Type 8 Due to CERS1 Deficiency: A Novel Mutation with Prominent Ataxia. Mov. Disord. Clin. Pract. 2018, 5, 330-332. [CrossRef]

16. Eckl, K.M.; Tidhar, R.; Thiele, H.; Oji, V.; Hausser, I.; Brodesser, S.; Preil, M.L.; Onal-Akan, A.; Stock, F.; Muller, D.; et al. Impaired epidermal ceramide synthesis causes autosomal recessive congenital ichthyosis and reveals the importance of ceramide acyl chain length. J. Investig. Dermatol. 2013, 133, 2202-2211. [CrossRef]

17. Mosbech, M.B.; Olsen, A.S.; Neess, D.; Ben-David, O.; Klitten, L.L.; Larsen, J.; Sabers, A.; Vissing, J.; Nielsen, J.E.; Hasholt, L.; et al. Reduced ceramide synthase 2 activity causes progressive myoclonic epilepsy. Ann. Clin. Trans. Neurol. 2014, 1, 88-98. [CrossRef]

18. Wegner, M.S.; Schiffmann, S.; Parnham, M.J.; Geisslinger, G.; Grosch, S. The enigma of ceramide synthase regulation in mammalian cells. Prog. Lipid Res. 2016, 63, 93-119. [CrossRef]

19. Skolova, B.; Kovacik, A.; Tesar, O.; Opalka, L.; Vavrova, K. Phytosphingosine, sphingosine and dihydrosphingosine ceramides in model skin lipid membranes: permeability and biophysics. Biochim. Biophys. Acta Biomembr. 2017, 1859, 824-834. [CrossRef]

20. Pant, D.C.; Dorboz, I.; Schluter, A.; Fourcade, S.; Launay, N.; Joya, J.; Aguilera-Albesa, S.; Yoldi, M.E.; Casasnovas, C.; Willis, M.J.; et al. Loss of the sphingolipid desaturase DEGS1 causes hypomyelinating leukodystrophy. J. Clin. Investig. 2019, 129, 1240-1256. [CrossRef]

21. Karsai, G.; Kraft, F.; Haag, N.; Korenke, G.C.; Hanisch, B.; Othman, A.; Suriyanarayanan, S.; Steiner, R.; Knopp, C.; Mull, M.; et al. DEGS1-associated aberrant sphingolipid metabolism impairs nervous system function in humans. J. Clin. Investig. 2019, 129, 1229-1239. [CrossRef]

22. Bienias, K.; Fiedorowicz, A.; Sadowska, A.; Prokopiuk, S.; Car, H. Regulation of sphingomyelin metabolism. Pharmaco. Rep. 2016, 68, 570-581. [CrossRef]

23. Pekkinen, M.; Terhal, P.A.; Botto, L.D.; Henning, P.; Makitie, R.E.; Roschger, P.; Jain, A.; Kol, M.; Kjellberg, M.A.; Paschalis, E.P.; et al. Osteoporosis and skeletal dysplasia caused by pathogenic variants in SGMS2. JCI Insight 2019, 4. [CrossRef]

24. Monies, D.; Anabrees, J.; Ibrahim, N.; Elbardisy, H.; Abouelhoda, M.; Meyer, B.F.; Alkuraya, F.S. Identification of a novel lethal form of autosomal recessive ichthyosis caused by UDP-glucose ceramide glucosyltransferase deficiency. Clin. Genet. 2018, 93, 1252-1253. [CrossRef]

25. Trinchera, M.; Parini, R.; Indellicato, R.; Domenighini, R.; dall'Olio, F. Diseases of ganglioside biosynthesis: An expanding group of congenital disorders of glycosylation. Mol. Genet. Metab. 2018, 124, 230-237. [CrossRef]

26. Ng, B.G.; Freeze, H.H. Perspectives on Glycosylation and Its Congenital Disorders. Trends Genet. 2018, 34, 466-476. [CrossRef]

27. Riboldi, G.M.; Di Fonzo, A.B. GBA, Gaucher Disease, and Parkinson's Disease: From Genetic to Clinic to New Therapeutic Approaches. Cells 2019, 8. [CrossRef]

28. Woeste, M.A.; Wachten, D. The Enigmatic Role of GBA2 in Controlling Locomotor Function. Frontiers in Mol. Neurosci. 2017, 10. [CrossRef]

29. Yu, F.P.S.; Amintas, S.; Levade, T.; Medin, J.A. Acid ceramidase deficiency: Farber disease and SMA-PME. Orphanet J. Rare Dis. 2018, 13, 121. [CrossRef]

30. Edvardson, S.; Yi, J.K.; Jalas, C.; Xu, R.; Webb, B.D.; Snider, J.; Fedick, A.; Kleinman, E.; Treff, N.R.; Mao, C.; et al. Deficiency of the alkaline ceramidase ACER3 manifests in early childhood by progressive leukodystrophy. J. Med. Genet. 2016, 53, 389-396. [CrossRef]

31. Dunn, T.M.; Tifft, C.J.; Proia, R.L. A perilous path: the inborn errors of sphingolipid metabolism. J. Lipid Res. 2019, 60, 475-483. [CrossRef] 
32. Alfonso, P.; Navascues, J.; Navarro, S.; Medina, P.; Bolado-Carrancio, A.; Andreu, V.; Irun, P.; Rodriguez-Rey, J.C.; Pocovi, M.; Espana, F.; et al. Characterization of variants in the glucosylceramide synthase gene and their association with type 1 Gaucher disease severity. Hum. Mutat. 2013, 34, 1396-1403. [CrossRef]

33. Mullin, S.; Hughes, D.; Mehta, A.; Schapira, A.H.V. Neurological effects of glucocerebrosidase gene mutations. Eur. J. Neurol. 2019, 26, 388-e29. [CrossRef]

34. de Souza, P.V.S.; de Rezende Pinto, W.B.V.; de Rezende Batistella, G.N.; Bortholin, T.; Oliveira, A.S.B. Hereditary Spastic Paraplegia: Clinical and Genetic Hallmarks. Cerebellum 2017, 16, 525-551. [CrossRef]

35. Edvardson, S.; Baumann, A.M.; Muhlenhoff, M.; Stephan, O.; Kuss, A.W.; Shaag, A.; He, L.; Zenvirt, S.; Tanzi, R.; Gerardy-Schahn, R.; et al. West syndrome caused by ST3Gal-III deficiency. Epilepsia 2013, 54, e24-e27. [CrossRef]

36. Schuchman, E.H.; Desnick, R.J. Types A and B Niemann-Pick disease. Mol. Genet. Metab. 2017, 120, $27-33$. [CrossRef]

37. Scott-Hewitt, N.J.; Folts, C.J.; Noble, M.D. Heterozygous carriers of galactocerebrosidase mutations that cause Krabbe disease have impaired microglial function and defective repair of myelin damage. Neural Regen. Res. 2018, 13, 393-401. [CrossRef]

38. Berger, J.R. Misdiagnosis of multiple sclerosis in a female heterozygote with Fabry's disease. Multiple sclerosis and related disorders 2019, 30, 45-47. [CrossRef]

39. Smith, L.; Mullin, S.; Schapira, A.H.V. Insights into the structural biology of Gaucher disease. Exp. Neurol. 2017, 298, 180-190. [CrossRef]

40. Erickson, A.H.; Ginns, E.I.; Barranger, J.A. Biosynthesis of the lysosomal enzyme glucocerebrosidase. J. Biol. Chem. 1985, 260, 14319-14324.

41. Berg-Fussman, A.; Grace, M.E.; Ioannou, Y.; Grabowski, G.A. Human acid beta-glucosidase. N-glycosylation site occupancy and the effect of glycosylation on enzymatic activity. J. Biol. Chem. 1993, 268, 14861-14866.

42. Liou, B.; Haffey, W.D.; Greis, K.D.; Grabowski, G.A. The LIMP-2/SCARB2 binding motif on acid beta-glucosidase: basic and applied implications for Gaucher disease and associated neurodegenerative diseases. J. Biol. Chem. 2014, 289, 30063-30074. [CrossRef]

43. Zunke, F.; Andresen, L.; Wesseler, S.; Groth, J.; Arnold, P.; Rothaug, M.; Mazzulli, J.R.; Krainc, D.; Blanz, J.; Saftig, P.; et al. Characterization of the complex formed by beta-glucocerebrosidase and the lysosomal integral membrane protein type-2. Proc. Natl. Acad. Sci. USA 2016, 113, 3791-3796. [CrossRef]

44. Martin, E.; Schule, R.; Smets, K.; Rastetter, A.; Boukhris, A.; Loureiro, J.L.; Gonzalez, M.A.; Mundwiller, E.; Deconinck, T.; Wessner, M.; et al. Loss of function of glucocerebrosidase GBA2 is responsible for motor neuron defects in hereditary spastic paraplegia. Am. J. Hum. Genet. 2013, 92, 238-244. [CrossRef]

45. Pandey, M.K.; Burrow, T.A.; Rani, R.; Martin, L.J.; Witte, D.; Setchell, K.D.; McKay, M.A.; Magnusen, A.F.; Zhang, W.; Liou, B.; et al. Complement drives glucosylceramide accumulation and tissue inflammation in Gaucher disease. Nature 2017, 543, 108-112. [CrossRef]

46. Beavan, M.; McNeill, A.; Proukakis, C.; Hughes, D.A.; Mehta, A.; Schapira, A.H. Evolution of prodromal clinical markers of Parkinson disease in a GBA mutation-positive cohort. JAMA Neuro. 2015, 72, 201-208. [CrossRef]

47. Gatto, E.M.; Da Prat, G.; Etcheverry, J.L.; Drelichman, G.; Cesarini, M. Parkinsonisms and Glucocerebrosidase Deficiency: A Comprehensive Review for Molecular and Cellular Mechanism of Glucocerebrosidase Deficiency. Brain Sci. 2019, 9. [CrossRef]

48. O’Regan, G.; deSouza, R.M.; Balestrino, R.; Schapira, A.H. Glucocerebrosidase Mutations in Parkinson Disease. J. Parkinson's Dis. 2017, 7, 411-422. [CrossRef]

49. Ysselstein, D.; Shulman, J.M.; Krainc, D. Emerging links between pediatric lysosomal storage diseases and adult parkinsonism. Mov. Disord. 2019, 34, 614-624. [CrossRef]

50. Gegg, M.E.; Schapira, A.H.V. The role of glucocerebrosidase in Parkinson disease pathogenesis. FEBS J. 2018, 285, 3591-3603. [CrossRef]

51. Sidransky, E.; Nalls, M.A.; Aasly, J.O.; Aharon-Peretz, J.; Annesi, G.; Barbosa, E.R.; Bar-Shira, A.; Berg, D.; Bras, J.; Brice, A.; et al. Multicenter analysis of glucocerebrosidase mutations in Parkinson's disease. N. Engl. J. Med. 2009, 361, 1651-1661. [CrossRef]

52. Hallett, P.J.; Huebecker, M.; Brekk, O.R.; Moloney, E.B.; Rocha, E.M.; Priestman, D.A.; Platt, F.M.; Isacson, O. Glycosphingolipid levels and glucocerebrosidase activity are altered in normal aging of the mouse brain. Neurobiol. Aging 2018, 67, 189-200. [CrossRef] 
53. Gegg, M.E.; Burke, D.; Heales, S.J.; Cooper, J.M.; Hardy, J.; Wood, N.W.; Schapira, A.H. Glucocerebrosidase deficiency in substantia nigra of parkinson disease brains. Ann. Neurol. 2012, 72, 455-463. [CrossRef]

54. Wong, Y.C.; Krainc, D. Lysosomal trafficking defects link Parkinson's disease with Gaucher's disease. Mov. Disord. 2016, 31, 1610-1618. [CrossRef]

55. Fussi, N.; Hollerhage, M.; Chakroun, T.; Nykanen, N.P.; Rosler, T.W.; Koeglsperger, T.; Wurst, W.; Behrends, C.; Hoglinger, G.U. Exosomal secretion of alpha-synuclein as protective mechanism after upstream blockage of macroautophagy. Cell Death Dis. 2018, 9, 757. [CrossRef]

56. Ikuno, M.; Yamakado, H.; Akiyama, H.; Parajuli, L.K.; Taguchi, K.; Hara, J.; Uemura, N.; Hatanaka, Y.; Higaki, K.; Ohno, K.; et al. GBA haploinsufficiency accelerates alpha-synuclein pathology with altered lipid metabolism in a prodromal model of Parkinson's disease. Hum. Mol. Genet. 2019, 28, 1894-1904. [CrossRef]

57. Gundner, A.L.; Duran-Pacheco, G.; Zimmermann, S.; Ruf, I.; Moors, T.; Baumann, K.; Jagasia, R.; van de Berg, W.D.J.; Kremer, T. Path mediation analysis reveals GBA impacts Lewy body disease status by increasing alpha-synuclein levels. Neurobiol. Dis. 2019, 121, 205-213. [CrossRef]

58. Sardi, S.P.; Viel, C.; Clarke, J.; Treleaven, C.M.; Richards, A.M.; Park, H.; Olszewski, M.A.; Dodge, J.C.; Marshall, J.; Makino, E.; et al. Glucosylceramide synthase inhibition alleviates aberrations in synucleinopathy models. Proc. Natl. Acad. Sci. USA 2017, 114, 2699-2704. [CrossRef]

59. Kim, M.J.; Jeon, S.; Burbulla, L.F.; Krainc, D. Acid ceramidase inhibition ameliorates alpha-synuclein accumulation upon loss of GBA1 function. Hum. Mol. Genet. 2018, 27, 1972-1988. [CrossRef]

60. Du, T.T.; Wang, L.; Duan, C.L.; Lu, L.L.; Zhang, J.L.; Gao, G.; Qiu, X.B.; Wang, X.M.; Yang, H. GBA deficiency promotes SNCA/alpha-synuclein accumulation through autophagic inhibition by inactivated PPP2A. Autophagy 2015, 11, 1803-1820. [CrossRef]

61. Thomas, R.E.; Vincow, E.S.; Merrihew, G.E.; MacCoss, M.J.; Davis, M.Y.; Pallanck, L.J. Glucocerebrosidase deficiency promotes protein aggregation through dysregulation of extracellular vesicles. PLoS Genet. 2018, 14, e1007694. [CrossRef]

62. Huang, Y.; Deng, L.; Zhong, Y.; Yi, M. The Association between E326K of GBA and the Risk of Parkinson's Disease. Parkinson's Dis. 2018, 2018, 1048084. [CrossRef]

63. Schmitz, M.; Alfalah, M.; Aerts, J.M.; Naim, H.Y.; Zimmer, K.P. Impaired trafficking of mutants of lysosomal glucocerebrosidase in Gaucher's disease. Int. J. Biochem. Cell Biol. 2005, 37, 2310-2320. [CrossRef]

64. Li, H.; Ham, A.; Ma, T.C.; Kuo, S.H.; Kanter, E.; Kim, D.; Ko, H.S.; Quan, Y.; Sardi, S.P.; Li, A.; et al. Mitochondrial dysfunction and mitophagy defect triggered by heterozygous GBA mutations. Autophagy 2019, 15, 113-130. [CrossRef]

65. Papadopoulos, V.E.; Nikolopoulou, G.; Antoniadou, I.; Karachaliou, A.; Arianoglou, G.; Emmanouilidou, E.; Sardi, S.P.; Stefanis, L.; Vekrellis, K. Modulation of beta-glucocerebrosidase increases alpha-synuclein secretion and exosome release in mouse models of Parkinson's disease. Hum. Mol. Genet. 2018, 27, 1696-1710. [CrossRef]

66. Thomas, R.; Kermode, A.R. Enzyme enhancement therapeutics for lysosomal storage diseases: Current status and perspective. Mol. Genet. Metab. 2019, 126, 83-97. [CrossRef]

67. Mohamed, F.E.; Al-Gazali, L.; Al-Jasmi, F.; Ali, B.R. Pharmaceutical Chaperones and Proteostasis Regulators in the Therapy of Lysosomal Storage Disorders: Current Perspective and Future Promises. Front. Pharmacol. 2017, 8, 448. [CrossRef]

68. Davidson, B.A.; Hassan, S.; Garcia, E.J.; Tayebi, N.; Sidransky, E. Exploring genetic modifiers of Gaucher disease: The next horizon. Hum. Mutat. 2018, 39, 1739-1751. [CrossRef]

69. Campbell, P.; Morris, H.; Schapira, A. Chaperone-mediated autophagy as a therapeutic target for Parkinson disease. Expert. Opin. Ther. Targets 2018, 22, 823-832. [CrossRef]

70. Foo, J.N.; Liany, H.; Bei, J.X.; Yu, X.Q.; Liu, J.; Au, W.L.; Prakash, K.M.; Tan, L.C.; Tan, E.K. Rare lysosomal enzyme gene SMPD1 variant (p.R591C) associates with Parkinson's disease. Neurobiol. Aging 2013, 34, 2890.e13-2890.e15. [CrossRef]

71. Alcalay, R.N.; Mallett, V.; Vanderperre, B.; Tavassoly, O.; Dauvilliers, Y.; Wu, R.Y.J.; Ruskey, J.A.; Leblond, C.S.; Ambalavanan, A.; Laurent, S.B.; et al. SMPD1 mutations, activity, and alpha-synuclein accumulation in Parkinson's disease. Mov. Disord. 2019, 34, 526-535. [CrossRef]

72. Wheeler, S.; Haberkant, P.; Bhardwaj, M.; Tongue, P.; Ferraz, M.J.; Halter, D.; Sprong, H.; Schmid, R.; Aerts, J.; Sullo, N.; et al. Cytosolic glucosylceramide regulates endolysosomal function in Niemann-Pick type C disease. Neurobiol. Dis. 2019, 127, 242-252. [CrossRef] 
73. Robak, L.A.; Jansen, I.E.; van Rooij, J.; Uitterlinden, A.G.; Kraaij, R.; Jankovic, J.; Heutink, P.; Shulman, J.M. Excessive burden of lysosomal storage disorder gene variants in Parkinson's disease. Brain 2017, 140, 3191-3203. [CrossRef]

74. Barmherzig, R.; Bullivant, G.; Cordeiro, D.; Sinasac, D.S.; Blaser, S.; Mercimek-Mahmutoglu, S. A New Patient With Intermediate Severe Salla Disease With Hypomyelination: A Literature Review for Salla Disease. Pediatr. Neurol. 2017, 74, 87-91. [CrossRef]

75. Mukherjee, A.B.; Appu, A.P.; Sadhukhan, T.; Casey, S.; Mondal, A.; Zhang, Z.; Bagh, M.B. Emerging new roles of the lysosome and neuronal ceroid lipofuscinoses. Mol. Neurodegener. 2019, 14, 4. [CrossRef]

76. Wise, A.H.; Yang, A.; Naik, H.; Stauffer, C.; Zeid, N.; Liong, C.; Balwani, M.; Desnick, R.J.; Alcalay, R.N. Parkinson's disease prevalence in Fabry disease: A survey study. Mol. Genet. Metab. reports 2018, 14, 27-30. [CrossRef]

77. Alcalay, R.N.; Wolf, P.; Levy, O.A.; Kang, U.J.; Waters, C.; Fahn, S.; Ford, B.; Kuo, S.H.; Vanegas, N.; Shah, H.; et al. Alpha galactosidase A activity in Parkinson's disease. Neurobiol. Dis. 2018, 112, 85-90. [CrossRef]

78. Chang, D.; Nalls, M.A.; Hallgrimsdottir, I.B.; Hunkapiller, J.; van der Brug, M.; Cai, F.; Kerchner, G.A.; Ayalon, G.; Bingol, B.; Sheng, M.; et al. A meta-analysis of genome-wide association studies identifies 17 new Parkinson's disease risk loci. Nat. Gene. 2017, 49, 1511-1516. [CrossRef]

79. Scott-Hewitt, N.J.; Folts, C.J.; Hogestyn, J.M.; Piester, G.; Mayer-Proschel, M.; Noble, M.D. Heterozygote galactocerebrosidase (GALC) mutants have reduced remyelination and impaired myelin debris clearance following demyelinating injury. Hum. Mol. Genet. 2017, 26, 2825-2837. [CrossRef]

80. Marshall, M.S.; Bongarzone, E.R. Beyond Krabbe's disease: The potential contribution of galactosylceramidase deficiency to neuronal vulnerability in late-onset synucleinopathies. J. Neurosci. Res. 2016, 94, 1328-1332. [CrossRef]

81. Folts, C.J.; Scott-Hewitt, N.; Proschel, C.; Mayer-Proschel, M.; Noble, M. Lysosomal Re-acidification Prevents Lysosphingolipid-Induced Lysosomal Impairment and Cellular Toxicity. PLoS Biol. 2016, 14, e1002583. [CrossRef]

82. Suzuki, K.; Yamaguchi, A.; Yamanaka, S.; Kanzaki, S.; Kawashima, M.; Togo, T.; Katsuse, O.; Koumitsu, N.; Aoki, N.; Iseki, E.; et al. Accumulated alpha-synuclein affects the progression of GM2 gangliosidoses. Exp. Neurol. 2016, 284, 38-49. [CrossRef]

83. Limphaibool, N.; Iwanowski, P.; Holstad, M.J.V.; Perkowska, K. Parkinsonism in Inherited Metabolic Disorders: Key Considerations and Major Features. Front. Neurol. 2018, 9, 857. [CrossRef]

84. Gaspar, R.; Pallbo, J.; Weininger, U.; Linse, S.; Sparr, E. Ganglioside lipids accelerate alpha-synuclein amyloid formation. Biochim. Biophys. Acta Proteins proteomics 2018. [CrossRef]

85. Kim, S.; Yun, S.P.; Lee, S.; Umanah, G.E.; Bandaru, V.V.R.; Yin, X.; Rhee, P.; Karuppagounder, S.S.; Kwon, S.H.; Lee, H.; et al. GBA1 deficiency negatively affects physiological alpha-synuclein tetramers and related multimers. Proc. Natl. Acad. Sci. USA 2018, 115, 798-803. [CrossRef]

86. Schneider, J.S. Altered expression of genes involved in ganglioside biosynthesis in substantia nigra neurons in Parkinson's disease. PloS ONE 2018, 13, e0199189. [CrossRef]

87. Chan, R.B.; Perotte, A.J.; Zhou, B.; Liong, C.; Shorr, E.J.; Marder, K.S.; Kang, U.J.; Waters, C.H.; Levy, O.A.; $\mathrm{Xu}$, Y.; et al. Elevated GM3 plasma concentration in idiopathic Parkinson's disease: A lipidomic analysis. PloS ONE 2017, 12, e0172348. [CrossRef]

88. Lutz, M.S.; Jaskiewicz, E.; Darling, D.S.; Furukawa, K.; Young, W.W., Jr. Cloned beta 1,4 $\mathrm{N}$-acetylgalactosaminyltransferase synthesizes GA2 as well as gangliosides GM2 and GD2. GM3 synthesis has priority over GA2 synthesis for utilization of lactosylceramide substrate in vivo. J. Biol. Chem. 1994, 269, 29227-29231.

89. Hidari, J.K.; Ichikawa, S.; Furukawa, K.; Yamasaki, M.; Hirabayashi, Y. beta 1-4N-acetylgalactosaminyltransferase can synthesize both asialoglycosphingolipid GM2 and glycosphingolipid GM2 in vitro and in vivo: isolation and characterization of a beta 1-4N-acetylgalactosaminyltransferase cDNA clone from rat ascites hepatoma cell line AH7974F. Biochem. J. 1994, 303, 957-965. [CrossRef]

90. Boukhris, A.; Schule, R.; Loureiro, J.L.; Lourenco, C.M.; Mundwiller, E.; Gonzalez, M.A.; Charles, P.; Gauthier, J.; Rekik, I.; Acosta Lebrigio, R.F.; et al. Alteration of ganglioside biosynthesis responsible for complex hereditary spastic paraplegia. Am. J. Hum. Genet. 2013, 93, 118-123. [CrossRef] 
91. Harlalka, G.V.; Lehman, A.; Chioza, B.; Baple, E.L.; Maroofian, R.; Cross, H.; Sreekantan-Nair, A.; Priestman, D.A.; Al-Turki, S.; McEntagart, M.E.; et al. Mutations in B4GALNT1 (GM2 synthase) underlie a new disorder of ganglioside biosynthesis. Brain 2013, 136, 3618-3624. [CrossRef]

92. Wakil, S.M.; Monies, D.M.; Ramzan, K.; Hagos, S.; Bastaki, L.; Meyer, B.F.; Bohlega, S. Novel B4GALNT1 mutations in a complicated form of hereditary spastic paraplegia. Clin. Genet. 2014, 86, 500-501. [CrossRef]

93. Bhuiyan, R.H.; Ohmi, Y.; Ohkawa, Y.; Zhang, P.; Takano, M.; Hashimoto, N.; Okajima, T.; Furukawa, K. Loss of Enzyme Activity in Mutated B4GALNT1 Gene Products in Patients with Hereditary Spastic Paraplegia Results in Relatively Mild Neurological Disorders: Similarity with Phenotypes of B4galnt1 Knockout Mice. Neuroscience 2019, 397, 94-106. [CrossRef]

94. Sheikh, K.A.; Sun, J.; Liu, Y.; Kawai, H.; Crawford, T.O.; Proia, R.L.; Griffin, J.W.; Schnaar, R.L. Mice lacking complex gangliosides develop Wallerian degeneration and myelination defects. Proc. Natl. Acad. Sci. USA 1999, 96, 7532-7537. [CrossRef]

95. Takamiya, K.; Yamamoto, A.; Furukawa, K.; Yamashiro, S.; Shin, M.; Okada, M.; Fukumoto, S.; Haraguchi, M.; Takeda, N.; Fujimura, K.; et al. Mice with disrupted GM2/GD2 synthase gene lack complex gangliosides but exhibit only subtle defects in their nervous system. Proc. Natl. Acad. Sci. USA 1996, 93, 10662-10667. [CrossRef]

96. Dick, K.J.; Eckhardt, M.; Paisan-Ruiz, C.; Alshehhi, A.A.; Proukakis, C.; Sibtain, N.A.; Maier, H.; Sharifi, R.; Patton, M.A.; Bashir, W.; et al. Mutation of FA2H underlies a complicated form of hereditary spastic paraplegia (SPG35). Hum. Mutat. 2010, 31, E1251-E1260. [CrossRef]

97. Hama, H. Fatty acid 2-Hydroxylation in mammalian sphingolipid biology. Biochim. Biophys. Acta 2010, 1801, 405-414. [CrossRef]

98. Boutry, M.; Branchu, J.; Lustremant, C.; Pujol, C.; Pernelle, J.; Matusiak, R.; Seyer, A.; Poirel, M.; Chu-Van, E.; Pierga, A.; et al. Inhibition of Lysosome Membrane Recycling Causes Accumulation of Gangliosides that Contribute to Neurodegeneration. Cell Rep. 2018, 23, 3813-3826. [CrossRef]

99. Sandhoff, R.; Schulze, H.; Sandhoff, K. Ganglioside Metabolism in Health and Disease. Prog. Mol. Biol. Transl. Sci. 2018, 156, 1-62. [CrossRef]

100. Indellicato, R.; Parini, R.; Domenighini, R.; Malagolini, N.; Iascone, M.; Gasperini, S.; Masera, N.; dall'Olio, F.; Trinchera, M. Total loss of GM3 synthase activity by a normally processed enzyme in a novel variant and in all ST3GAL5 variants reported to cause a distinct congenital disorder of glycosylation. Glycobiology 2019, 29, 229-241. [CrossRef]

101. Simpson, M.A.; Cross, H.; Proukakis, C.; Priestman, D.A.; Neville, D.C.; Reinkensmeier, G.; Wang, H.; Wiznitzer, M.; Gurtz, K.; Verganelaki, A.; et al. Infantile-onset symptomatic epilepsy syndrome caused by a homozygous loss-of-function mutation of GM3 synthase. Nat. Genet. 2004, 36, 1225-1229. [CrossRef]

102. Boccuto, L.; Aoki, K.; Flanagan-Steet, H.; Chen, C.F.; Fan, X.; Bartel, F.; Petukh, M.; Pittman, A.; Saul, R.; Chaubey, A.; et al. A mutation in a ganglioside biosynthetic enzyme, ST3GAL5, results in salt \& pepper syndrome, a neurocutaneous disorder with altered glycolipid and glycoprotein glycosylation. Hum. Mol. Genet. 2014, 23, 418-433. [CrossRef]

103. Lee, J.S.; Yoo, Y.; Lim, B.C.; Kim, K.J.; Song, J.; Choi, M.; Chae, J.H. GM3 synthase deficiency due to ST3GAL5 variants in two Korean female siblings: Masquerading as Rett syndrome-like phenotype. Am. J. Med. Geneti. Part A 2016, 170, 2200-2205. [CrossRef]

104. Bowser, L.E.; Young, M.; Wenger, O.K.; Ammous, Z.; Brigatti, K.W.; Carson, V.J.; Moser, T.; Deline, J.; Aoki, K.; Morlet, T; et al. Recessive GM3 synthase deficiency: Natural history, biochemistry, and therapeutic frontier. Mol. Genet. Metab. 2019. [CrossRef]

105. Furukawa, K.; Ohmi, Y.; Ji, S.; Zhang, P.; Bhuiyan, R.H.; Ohkawa, Y.; Tajima, O.; Hashimoto, N. Glycolipids: Essential regulator of neuro-inflammation, metabolism and gliomagenesis. Biochim. Biophys. Acta General subjects 2017, 1861, 2479-2484. [CrossRef]

106. Yamashita, T.; Hashiramoto, A.; Haluzik, M.; Mizukami, H.; Beck, S.; Norton, A.; Kono, M.; Tsuji, S.; Daniotti, J.L.; Werth, N.; et al. Enhanced insulin sensitivity in mice lacking ganglioside GM3. Proc. Natl. Acad. Sci. USA 2003, 100, 3445-3449. [CrossRef]

107. Yoshikawa, M.; Go, S.; Takasaki, K.; Kakazu, Y.; Ohashi, M.; Nagafuku, M.; Kabayama, K.; Sekimoto, J.; Suzuki, S.; Takaiwa, K.; et al. Mice lacking ganglioside GM3 synthase exhibit complete hearing loss due to selective degeneration of the organ of Corti. Proc. Natl. Acad. Sci. USA 2009, 106, 9483-9488. [CrossRef] 
108. Carvalho, A.S.; Harduin-Lepers, A.; Magalhaes, A.; Machado, E.; Mendes, N.; Costa, L.T.; Matthiesen, R.; Almeida, R.; Costa, J.; Reis, C.A. Differential expression of alpha-2,3-sialyltransferases and alpha-1,3/4-fucosyltransferases regulates the levels of sialyl Lewis a and sialyl Lewis $\mathrm{x}$ in gastrointestinal carcinoma cells. The international journal of biochemistry $\mathcal{E}$ cell biology 2010, 42, 80-89. [CrossRef]

109. Kitagawa,H.; Paulson, J.C. Cloning and expression of human Gal beta 1,3(4)GlcNAc alpha 2,3-sialyltransferase. Biochem Bioph Res Commun. 1993, 194, 375-382. [CrossRef]

110. Kono, M.; Ohyama, Y.; Lee, Y.C.; Hamamoto, T.; Kojima, N.; Tsuji, S. Mouse beta-galactoside alpha 2,3-sialyltransferases: comparison of in vitro substrate specificities and tissue specific expression. Glycobiology 1997, 7, 469-479. [CrossRef]

111. Sturgill, E.R.; Aoki, K.; Lopez, P.H.; Colacurcio, D.; Vajn, K.; Lorenzini, I.; Majic, S.; Yang, W.H.; Heffer, M.; Tiemeyer, M.; et al. Biosynthesis of the major brain gangliosides GD1a and GT1b. Glycobiology 2012, 22, 1289-1301. [CrossRef]

112. Aronica, A.; Avagliano, L.; Caretti, A.; Tosi, D.; Bulfamante, G.P.; Trinchera, M. Unexpected distribution of CA19.9 and other type 1 chain Lewis antigens in normal and cancer tissues of colon and pancreas: Importance of the detection method and role of glycosyltransferase regulation. Biochim. Biophys. Acta General subjects 2017, 1861, 3210-3220. [CrossRef]

113. Zulueta, A.; Caretti, A.; Signorelli, P.; Dall'olio, F.; Trinchera, M. Transcriptional control of the B3GALT5 gene by a retroviral promoter and methylation of distant regulatory elements. FASEB J. 2014, 28, 946-955. [CrossRef]

114. Mare, L.; Caretti, A.; Albertini, R.; Trinchera, M. CA19.9 antigen circulating in the serum of colon cancer patients: where is it from? Int. J. Biochem. Cell Biol. 2013, 45, 792-797. [CrossRef]

115. Hu, H.; Eggers, K.; Chen, W.; Garshasbi, M.; Motazacker, M.M.; Wrogemann, K.; Kahrizi, K.; Tzschach, A.; Hosseini, M.; Bahman, I.; et al. ST3GAL3 mutations impair the development of higher cognitive functions. Am. J. Hum. Genet. 2011, 89, 407-414. [CrossRef]

116. van Diepen, L.; Buettner, F.F.R.; Hoffmann, D.; Thiesler, C.T.; von Bohlen Und Halbach, O.; von Bohlen Und Halbach, V.; Jensen, L.R.; Steinemann, D.; Edvardson, S.; Elpeleg, O.; et al. A patient-specific induced pluripotent stem cell model for West syndrome caused by ST3GAL3 deficiency. Eur.J. Hum. Geneti. 2018, 26, 1773-1783. [CrossRef]

117. Ellies, L.G.; Sperandio, M.; Underhill, G.H.; Yousif, J.; Smith, M.; Priatel, J.J.; Kansas, G.S.; Ley, K.; Marth, J.D. Sialyltransferase specificity in selectin ligand formation. Blood 2002, 100, 3618-3625. [CrossRef]

118. Kiwamoto, T.; Brummet, M.E.; Wu, F.; Motari, M.G.; Smith, D.F.; Schnaar, R.L.; Zhu, Z.; Bochner, B.S. Mice deficient in the St3gal3 gene product alpha2,3 sialyltransferase (ST3Gal-III) exhibit enhanced allergic eosinophilic airway inflammation. J. Allergy Clin. Immunol. 2014, 133, 240-247. [CrossRef]

119. Menzies, F.M.; Fleming, A.; Caricasole, A.; Bento, C.F.; Andrews, S.P.; Ashkenazi, A.; Fullgrabe, J.; Jackson, A.; Jimenez Sanchez, M.; Karabiyik, C.; et al. Autophagy and Neurodegeneration: Pathogenic Mechanisms and Therapeutic Opportunities. Neuron 2017, 93, 1015-1034. [CrossRef]

120. van Echten-Deckert, G.; Alam, S. Sphingolipid metabolism-An ambiguous regulator of autophagy in the brain. Biological chemistry 2018, 399, 837-850. [CrossRef]

121. Qiang, L.; Piermarini, E.; Baas, P.W. New Hypothesis for the Etiology of SPAST-based Hereditary Spastic Paraplegia. Cytoskeleton 2019. [CrossRef]

122. Fragaki, K.; Ait-El-Mkadem, S.; Chaussenot, A.; Gire, C.; Mengual, R.; Bonesso, L.; Beneteau, M.; Ricci, J.E.; Desquiret-Dumas, V.; Procaccio, V.; et al. Refractory epilepsy and mitochondrial dysfunction due to GM3 synthase deficiency. Eur. J. Hum. Genet. 2013, 21, 528-534. [CrossRef]

123. Kiebish, M.A.; Han, X.; Cheng, H.; Lunceford, A.; Clarke, C.F.; Moon, H.; Chuang, J.H.; Seyfried, T.N. Lipidomic analysis and electron transport chain activities in C57BL/6J mouse brain mitochondria. J. Neurochem. 2008, 106, 299-312. [CrossRef]

124. Saffari, A.; Kolker, S.; Hoffmann, G.F.; Ebrahimi-Fakhari, D. Linking mitochondrial dysfunction to neurodegeneration in lysosomal storage diseases. J. Inherit. Metab. Dis. 2017, 40, 631-640. [CrossRef]

125. Sahu, S.K.; Hannun, Y.A.; Yao, N. Emergence of membrane sphingolipids as a potential therapeutic target. Biochimie 2019, 158, 257-264. [CrossRef]

126. Cui, Y.; Hettinghouse, A.; Liu, C.J. Progranulin: A conductor of receptors orchestra, a chaperone of lysosomal enzymes and a therapeutic target for multiple diseases. Cytokine Growth Factor Rev. 2019, 45, 53-64. [CrossRef] 
127. Zielonka, M.; Garbade, S.F.; Kölker, S.; Hoffmann, G.F.; Ries, M. A cross-sectional quantitative analysis of the natural history of Farber disease: an ultra-orphan condition with rheumatologic and neurological cardinal disease features. Genetet. Med. 2018, 20, 524-530. [CrossRef]

128. Coant, N.; Sakamoto, W.; Mao, C.; Hannun, Y.A. Ceramidases; roles in sphingolipid metabolism and in health and disease. Adv. Biol. Regul. 2017, 63, 122-131. [CrossRef]

129. Li, F.; Xu, R.; Low, B.E.; Lin, CL.; Garcia-Barros, M.; Schrandt, J.; Mileva, I.; Snider, A.; Luo, C.K.; Jiang, X.C.; et al. Alkaline ceramidase 2 is essential for the homeostasis of plasma sphingoid bases and their phosphates. FASEB J. 2018, 32, 3058-3069. [CrossRef]

130. Hatoum, D.; Haddadi, N.; Lin, Y.; Nassif, N.T.; McGowan, E.M. Mammalian sphingosine kinase (SphK) isoenzymes and isoform expression: challenges for SphK as an oncotarget. Oncotarget 2017, 8, 36898-36929. [CrossRef]

131. Lovric, S.; Goncalves, S.; Gee, H.Y.; Oskouian, B.; Srinivas, H.; Choi, W.I.; Shril, S.; Ashraf, S.; Tan, W.; Rao, J.; et al. Mutations in sphingosine-1-phosphate lyase cause nephrosis with ichthyosis and adrenal insufficiency. J. Clin. Investig. 2017, 127, 912-928. [CrossRef]

132. Oliveira, J.P.; Ferreira, S. Multiple phenotypic domains of Fabry disease and their relevance for establishing genotype- phenotype correlations. Appl. Clin. Genet. 2019, 12, 35-50. [CrossRef] [PubMed]

(C) 2019 by the authors. Licensee MDPI, Basel, Switzerland. This article is an open access article distributed under the terms and conditions of the Creative Commons Attribution (CC BY) license (http://creativecommons.org/licenses/by/4.0/). 